Geosci. Model Dev. Discuss., https://doi.org/10.5194/gmd-2018-128

Manuscript under review for journal Geosci. Model Dev.

Discussion started: 21 June 2018

(c) Author(s) 2018. CC BY 4.0 License.

\title{
NHM-Chem, the Japan Meteorological Agency's regional meteorology - chemistry model (v1.0): model description and aerosol representations
}

Mizuo Kajino ${ }^{1,2}$, Makoto Deushi ${ }^{1}$, Tsuyoshi Thomas Sekiyama ${ }^{1}$, Naga Oshima ${ }^{1}$, Keiya Yumimoto ${ }^{3,1}$, 5 Taichu Yasumichi Tanaka ${ }^{1}$, Joseph Ching ${ }^{1}$, Akihiro Hashimoto ${ }^{1}$, Tetsuya Yamamoto ${ }^{1}$, Masaaki Ikegami $^{4}$, Akane Kamada ${ }^{4}$, Makoto Miyashita ${ }^{4}$, Yayoi Inomata ${ }^{5,1}$, Shin-ichiro Shima ${ }^{6}$, Kouji Adachi ${ }^{1}$, Yuji Zaizen ${ }^{1}$, Yasuhito Igarashi ${ }^{7,1}$, Hiromasa Ueda ${ }^{8}$, Takashi Maki ${ }^{1}$, and Masao Mikami ${ }^{9,1}$

${ }^{1}$ Meteorological Research Institute, Japan Meteorological Agency, Tsukuba, 305-0052, Japan

${ }^{2}$ Faculty of Life and Environmental Sciences, University of Tsukuba, Tsukuba, 305-8577, Japan

$10{ }^{3}$ Research Institute for Applied Mechanics, Kyushu University, Kasuga, 816-8580, Japan

${ }^{4}$ Japan Meteorological Agency, Chiyoda, 100-8122, Japan

${ }^{5}$ Institute of Nature and Environmental Technology, Kanazawa University, Kanazawa, 920-1192, Japan

${ }^{6}$ Graduate School of Simulation Studies, University of Hyogo, Kobe, 650-0047, Japan

${ }^{7}$ College of Science, Ibaraki University, Mito, 310-8512, Japan

$15{ }^{8}$ Disaster Prevention Research Institute, Kyoto University, Uji, 611-0011, Japan

${ }^{9}$ Japan Meteorological Business Support Center, Chiyoda, 101-0054, Japan

Correspondence to: Mizuo Kajino (kajino@mri-jma.go.jp)

20 aerosol representations are currently available: the 5-category non-equilibrium (Aitken, soot-free accumulation, accumulation internally mixed with soot, dust, and sea-salt), 3-category non-equilibrium (Aitken, accumulation, and coarse), and bulk equilibrium (submicron, dust, and sea-salt) methods. These three methods are suitable for the predictions of regional climate, air quality, and operational forecasts, respectively. The total CPU times of the 5-category and 3-category methods were $91 \%$ and $44 \%$ greater than that of the bulk method, respectively. The bulk equilibrium method was shown to be eligible for operational forecast purposes, namely, the surface mass concentrations of air pollutants such as $\mathrm{O}_{3}$, mineral dust, and $\mathrm{PM}_{2.5}$. The 3-category method was shown to be eligible for air quality simulations, namely, mass concentrations and depositions. However, the internal mixture assumption of soot/soot-free and dust/sea-salt particles in the 3-category method resulted in significant differences in the size distribution and hygroscopicity of the particles. Even though the 3category method was not designed to simulate aerosol-cloud-radiation interaction processes, its performance in terms of bulk properties, such as aerosol optical thickness (AOT) and cloud condensation nuclei (CCN), was acceptable. However, some specific parameters exhibited significant differences or systematic errors. The unrealistic dust/sea-salt complete mixture of the 3-category method induced significant errors in the prediction of mineral dust containing CCN. The overestimation of soot hygroscopicity by the 3-category method induced errors in $\mathrm{BC}$-containing $\mathrm{CCN}, \mathrm{BC}$ deposition, and absorbing AOT 
Geosci. Model Dev. Discuss., https://doi.org/10.5194/gmd-2018-128

Manuscript under review for journal Geosci. Model Dev.

Discussion started: 21 June 2018

(c) Author(s) 2018. CC BY 4.0 License.

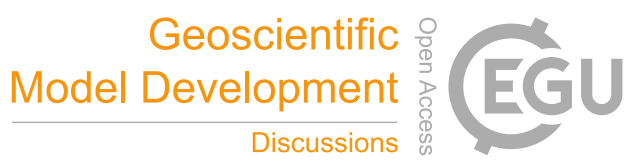

(AAOT). The difference in AAOT was less pronounced because the overestimation of the absorption enhancement was compensated by the overestimation of hygroscopic growth and the consequent loss due to in-cloud scavenging.

\section{Introduction}

Atmospheric aerosols scatter and absorb solar and terrestrial radiation and thus contribute to warming and cooling on

5 regional to global scales. Aerosols also affect regional to global climate through aerosol-cloud-radiation interactions in various ways (Boucher et al., 2013). Aerosols together with the relevant gases can have negative impacts on ecosystems and health, such as photochemical oxidants, acid deposition, persistent organic pollutants (POPs), polycyclic aromatic hydrocarbons (PAHs), radioactive nuclides, metals, and $\mathrm{PM}_{2.5}$ (WHO, 2001; Cohen et al., 2004; Burns et al., 2011).

Due to the high complexity of atmospheric aerosol properties, such as size, composition, morphology, and mixing

10 state, there exists a variety of aerosol representations used in the atmospheric models. Historically, climate models have assumed external mixtures of aerosols (e.g., Tanaka et al., 2003; Takemura et al., 2005), whereas chemical transport models have assumed internal mixtures (e.g., Sudo et al., 2002; Emmons et al., 2010). The representation of external mixtures of aerosol is more computationally efficient for climate models (i.e., the number of tracers is the number of categories), whereas the representation of internal mixtures is more efficient for chemical transport models, considering that they contain

15 hundreds of reactions and tens of chemical components (i.e., the number of tracers is the number of components multiplied by the number of modes, sections, or categories). However, in reality, coarse mode particles such as sea-salt and dust are more externally mixed, whereas submicron particles are more internally mixed and comprise mixtures of inorganic and organic compounds in each particle (e.g., Adachi et al., 2010). Based on this fact, the category approach (e.g., Jacobson, 2002) to express the mixing state of aerosols has been developed and used in both climate models (e.g., Zhang et al., 2012a;

20 Liu et al., 2012, 2016) and chemical transport models (e.g., Vogel et al., 2009; Kajino and Kondo, 2011; Kajino et al., 2012a; this study). In terms of black carbon (BC), mixing state resolving models have been developed (Oshima et al., 2009a; Ching et al., 2016a; Matsui, 2017) to explicitly treat the hydrophobic to hygroscopic changes in BC-containing particles and increases in light absorption amplification and in-cloud scavenging efficiency through condensational growth during transport. The ultimate representation of the mixing state is a single particle resolving model to express a continuous mixing 25 state (or an intermediate state of aerosol mixing) (Zaveri et al., 2010), which has been implemented to a 1-D framework (Curtis et al., 2017); 3-D implementation is currently ongoing. Still, however, computational resources are limited, and there are many important processes in addition to aerosol representations. It is essential to incorporate enough efficient but realistic aerosol representations in meteorology - chemistry coupled models, with an awareness of the impacts of the aerosol mixing state on the bulk properties of populations of aerosols, as assessed by a series of single particle-based studies (e.g., Zaveri et al., 2010; Ching et al., 2012; 2016b; 2017; 2018).

From the context mentioned above, in order to simulate regional climate, air quality, and chemical weather forecast, a regional-scale meteorology - chemistry model has been developed. Three options for aerosol representations, i.e., 5- 
Geosci. Model Dev. Discuss., https://doi.org/10.5194/gmd-2018-128

Manuscript under review for journal Geosci. Model Dev.

Discussion started: 21 June 2018

(c) Author(s) 2018. CC BY 4.0 License.

Geoscientific
Model Development

Discussions

category non-equilibrium, 3-category non-equilibrium and bulk equilibrium representations, are incorporated for the three respective purposes of regional climate, air quality, and operational forecast. The 3-category method is a global standard method that has been widely used in various regional-scale chemical transport models (e.g., Grell et al., 2005; Byun and Schere, 2006), whereas the 5-category and bulk equilibrium methods are unique. The model descriptions, with a focus on the

5 differences between the three options, are given in Sect. 2. The model evaluations using the chemical and optical observation data are performed in terms of consistent predictions of the chemical - physical - optical properties of aerosols and the consistent predictions of the regional budget (emission - transport - transformation - deposition) and are presented in a separate paper (Kajino et al., 2018a). The current paper focuses on the difference in the model performances due to the selection of the three aerosol category methods, as presented and discussed in Sect. 3. Conclusions are summarized in Sect. 4.

102 Model description

2.1 Meteorology model and coupling with chemical transport model

The Japan Meteorological Agency (JMA)'s non-hydrostatic model (NHM, cf., Saito et al., 2006, 2007) is used to simulate meteorological fields. NHM-Chem is coupled with NHM either offline or online. NHM was developed and used for the operational weather forecasting of JMA and currently the next generation non-hydrostatic model, asuca is used. The online coupling version is currently available, but it uses a simpler representation of the aerosol category (similar to the current bulk equilibrium method, but without SS and DU categories). The development of online coupling with the three aerosol methods presented in this paper is currently ongoing. The chemistry to meteorology feedback process has not been included and will be implemented in the near future. Therefore, as the first step, the simulation results obtained with the offline-coupling version were presented and compared in this paper. In the offline-coupling framework, a multi-meteorological model ensemble can be readily performed: we only need an interface to convert a meteorological model output to a chemical model input. Currently, an interface with the Weather Research and Forecast model (WRF; Skamarock et al., 2008) is implemented to NHM-Chem, and an interface with the next-generation non-hydrostatic model of JMA, asuca (JMA, 2014), is currently being developed. Kajino et al. (2018b) evaluated the impact of the uncertainty in meteorological simulations on the modeling of chemical transport and deposition by using NHM, NHM-LETKF (Local ensemble transform Kalman filter data

25 assimilation method coupled with NHM; Kunii, 2014; Sekiyama et al., 2015), and WRF with several combinations of turbulence and cloud microphysics modules.

\subsection{Chemical transport model}

Table 1 summarizes the schemes of the chemical transport model (CTM) and database used in this study. The CTM part (or Chem) of NHM-Chem is a successive extension of Regional Air Quality Model 2 (RAQM2; Kajino et al., 2012a) and thus

30 many of the schemes are in common. For the offline-coupled NHM-Chem, the horizontal grid of the CTM is identical to that of meteorological models, but the vertical coordinate is different; thus, users can reduce the number of vertical layers or the 
Geosci. Model Dev. Discuss., https://doi.org/10.5194/gmd-2018-128

Manuscript under review for journal Geosci. Model Dev.

Discussion started: 21 June 2018

(c) Author(s) 2018. CC BY 4.0 License.

model top height for increased computational efficiency, or they can use different meteorological models that use different vertical coordinates. To reduce the mass divergence due to vertical interpolation to approximately $10^{-5}$ to $10^{-6}\left(\mathrm{~s}^{-1}\right)$, the mass continuity model (Ishikawa, 1994) is incorporated to the meteorology - chemistry model interface of the offline-coupled NHM-Chem. Because the vertical coordinates of the CTM and NHM are identical, the mass continuity model is not needed

5 for the online-coupled NHM-Chem.

The details of the chemical and aerosol microphysical schemes in the CTM part of NHM-Chem are not repeated in this paper, because most of them have not been updated since Kajino et al. (2012a), except for the aerosol representations, which have been significantly updated and are thus described in the next section (Sect. 2.3). As listed in Table 1, the methods used to calculate advection, turbulent diffusion, the photolysis rate and gas-phase chemistry, secondary organic 10 aerosol chemistry, and liquid phase chemistry are the same as those used by Kajino et al. (2012a), except for the three heterogeneous chemical reactions of $\mathrm{N}_{2} \mathrm{O}_{5}, \mathrm{HO}_{2}$, and $\mathrm{NO}_{2}$ from Jacob (2000) included in the SAPRC99 gas-phase chemistry mechanism (Carter, 2000). For the aerosol microphysics calculations, the triple-moment modal method (Kajino, 2011) is used. A log-normal size distribution is assumed for the aerosol populations. There are three parameters used to identify the log-normal function, namely, the number concentration, geometric mean diameter $D_{\mathrm{g}}$, and geometric standard deviation $\sigma_{\mathrm{g}}$.

15 The three moments of the number, surface area, and mass concentrations of aerosols are selected to fix the log-normal parameters and are transported in the simulation. This is how the log-normal parameters of aerosol populations are changed in a physically consistent manner during the entire process of the simulation. Although Kajino (2011) accounted for the fractal shapes of particles (as implemented by Kajino and Kondo, 2011 in the 3-D CTM framework), currently, all particles are assumed to be spherical for aerosol microphysics purposes. A spherical shape is also assumed for the calculations of the

20 optical properties of aerosols. The aerosol microphysics calculation algorithm was described in detail by Kajino et al. (2012a). The methods used to calculate the new particle formation, surface equilibrium vapor pressures of inorganic and organic compounds, condensation/evaporation, Brownian coagulation, dry deposition, in-cloud scavenging (e.g., cloud condensation nuclei (CCN) activation, ice nuclei (IN) activation, and subsequent cloud microphysics processes), and subgrid-scale convection and scavenging are the same as those used by Kajino et al. (2012a), whereas the fog deposition

25 parameterization of Katata et al. (2015) and the detailed below-cloud scavenging scheme have been newly incorporated, as described below.

Katata et al. (2015) developed a parameterization to calculate the fog deposition velocity as a function of the land use category (LUC), leaf area index (LAI), and 10-m wind speed. Fog deposition is calculated only in the bottom layer of the model, where the cloud water content is greater than $10^{-5} \mathrm{~kg} \mathrm{~kg}^{-1}$. Fog deposition may not be pronounced in regional-scale simulations, such as the current study $(\Delta x>10 \mathrm{~km})$, but it could be significant in local-scale simulations $(\Delta x \sim 1 \mathrm{~km})$. The large simulated proportions of radioactive Cs deposition in Tochigi and Gunma prefectures associated with the Fukushima nuclear accident were due to fog deposition (Kajino et al., 2018b).

The large discrepancy between the theoretical and experimental rates of below-cloud scavenging has been a critical issue and has not yet been resolved (Wang et al., 2010; Zhang et al., 2013). The theoretical rates are sometimes one to two 
Geosci. Model Dev. Discuss., https://doi.org/10.5194/gmd-2018-128

Manuscript under review for journal Geosci. Model Dev.

Discussion started: 21 June 2018

(c) Author(s) 2018. CC BY 4.0 License.

orders of magnitude smaller than the empirical rates, especially for aerosols that are in the diameter ranges of approximately $1 \mu \mathrm{m}$, which have Brownian motion and an inertial force that are both small. In the current implementation, we proposed two options for below-cloud scavenging, namely, the conventional modal method developed by Kajino and Kondo (2011) (as used in Kajino et al., 2012a) and a newly implemented method using detailed size-resolved parameterizations. The latter

5 option takes longer computational time because it is size-resolved, but the Gauss-Hermite quadrature method is used to minimize the computational time (however, it is still expensive). Slinn (1984)'s parameterization, which considers thermophoresis, diffusiophoresis, and electrostatic forces (Andronache et al., 2006), is used for the derivation of the collection efficiencies of aerosols by rain droplets. There are two options to calculate the efficiencies collected by snow and graupel particles, i.e., those of Slinn (1984) and Murakami (1985).

\section{$10 \quad 2.3$ Aerosol representation options}

There are currently three options for the representations of aerosol categories (or types), i.e., the 5-category non-equilibrium method, the 3-category non-equilibrium method, and the bulk equilibrium method (Fig. 1). The prognostic variables of the aerosol attributes of these three methods are listed in Table 2. Each elementary process is depicted by a colored arrow in Fig. 1. Here, the term "bulk equilibrium" indicates that the gas-aerosol partitioning of inorganic semi-volatile components, such

15 as $\mathrm{NH}_{3}-\mathrm{NH}_{4}{ }^{+} \mathrm{HNO}_{3}-\mathrm{NO}_{3}{ }^{-}$, and $\mathrm{HCl}-\mathrm{Cl}^{-}$, is instantaneously obtained at the "equilibrium" state of the "bulk" component assumption (each component is summed from all categories). On the other hand, in the non-equilibrium methods, mass transfer coefficients are calculated for each category based on its size distribution, and condensation or evaporation is driven by the mass transfer coefficients multiplied by the differences between the equilibrium state and the current state of each category (see Eqs. 13-16 of Kajino et al., 2012a).

The 3-category method (ATK: Aitken mode, ACM: accumulation mode, COR: coarse mode) is a global standard method widely used in regional-scale CTMs, such as WRF-Chem and CMAQ. These models were originally developed for the purpose of air quality predictions, such as acid deposition, photochemical oxidants, and $\mathrm{PM}_{2.5}$ (Byun and Schere, 2006; Grell et al., 2005); however, they have recently been used to perform regional climate predictions through aerosol-cloudradiation interaction processes (Chapman et al., 2009; Wong et al., 2012; Kajino et al., 2017). However, the 3-category method does not consider the two aspects that are critically important in climate simulations and are thus often resolved by climate models: (1) differences between light-absorbing and non-light-absorbing aerosols and (2) differences between mineral dust and sea-salt particles. To consider these two differences, the 5-category method is implemented by dividing the accumulation mode (ACM of the 3-category method) into the ACM (soot-free accumulation mode) and AGR (accumulation mode mixed with soot aggregate) categories and dividing the coarse mode (COR of the 3-category method) into the DU (mixture with dust; i.e., both mineral and anthropogenic dust) and SS (mixture with sea-salt) categories.

$\mathrm{BC}$ is a strong light-absorbing agent and thus alters the climate by heating the air (Bond et al., 2013 and references therein). $\mathrm{BC}$ is usually hydrophobic when emitted and becomes more hygroscopic due to the condensational growth of water-soluble inorganics, such as sulfate $\left(\mathrm{SO}^{2-}\right)$, nitrate $\left(\mathrm{NO}_{3}{ }^{-}\right)$, and ammonium $\left(\mathrm{NH}_{4}{ }^{+}\right)$, during transport. The in-cloud 
Geosci. Model Dev. Discuss., https://doi.org/10.5194/gmd-2018-128

Manuscript under review for journal Geosci. Model Dev.

Discussion started: 21 June 2018

(c) Author(s) 2018. CC BY 4.0 License.

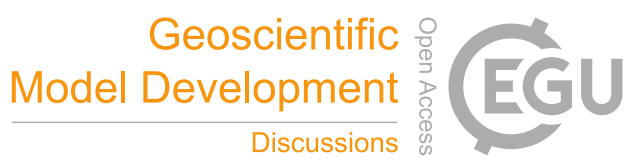

scavenging of BC, which is the major removal process of BC (Kondo et al., 2011), highly depends on the mixing state of BC (Ching et al., 2012; 2016b; 2018). Certainly, the 5-category method cannot resolve the mixing state of BC; however, it can simulate the bulk amounts condensed onto BC vs. non-BC particles, whereas the 3-category method cannot. Thus, the 3category method will apparently overestimate the condensational growth of $\mathrm{BC}$ and therefore overestimate its hygroscopicity,

5 in-cloud scavenging, and subsequent heterogeneous ice nucleation (i.e., immersion and condensation freezing). All of the $\mathrm{SO}_{4}{ }^{2-}$ and $\mathrm{NO}_{3}{ }^{-}$condense onto $\mathrm{BC}$ in the 3-category method, although major proportions of $\mathrm{SO}_{4}{ }^{2-}$ and $\mathrm{NO}_{3}{ }^{-}$are mixed with non-BC particles in reality (Miyakawa et al., 2014). The degree of overestimation caused by the 3-category method relative to the 5-category method is presented later in Sect. 3.4.

The 3-category method assumes a completely internal mixture of dust and sea-salt when the two particles coexist in the same grid box, although the chemical and physical properties of these two particles are totally different. Certainly, some proportions of dust/sea-salt mixtures exist in the dust plume coming across the ocean to Japan (Zhang and Iwasaka, 2004). Mineral dust is hydrophobic and non-spherical when emitted and thus shows high IN activity, is light-absorbing, becomes hygroscopic during transport, and invigorates heterogeneous reactions (Kameda et al., 2016). On the other hand, sea-salt is highly hygroscopic and is thus an efficient CCN. The size distributions of mineral dust and sea-salt are also very different,

15 but their size distributions and hygroscopicity merge into unrealistic ones (i.e., the intermediate values, which are different from those of both particles, as shown later in Sect. 3) when the two particles coexist in the same grid box. This 3-category representation would be adequate for predicting the air pollution over a continent, such as Europe or America. It would also be safe for global climate simulations because on average, the major global proportions of dust and sea-salt exist separately in different locations, namely, over the continents and oceans, respectively. However, for cases of long-range transport over

20 the Asian continent to Japan, mineral dust and anthropogenic pollutants travel in the sea-salt-rich boundary layer over the ocean. As discussed in Sect. 3, the 3-category method is thus not suitable for air quality and regional climate predictions in East Asia. Thus, the 5-category method is regarded as the standard method of NHM-Chem.

The 5-category and 3-category methods solve full aerosol microphysical processes by using the triple-moment modal method presented in the previous section (see red, blue, and pink arrows in Figs. 1a and 1b). Even though a modal approach is used, which is basically computationally efficient compared to a sectional approach, it is still time-consuming because NHM-Chem explicitly models the homogeneous nucleation of sulfuric acid gas to produce $1 \mathrm{~nm}$ particles and their subsequent growth due to condensation and coagulation.

In terms of the operational forecasts of air quality, such as photochemical oxidants, mineral dust, and $\mathrm{PM}_{2.5}$, the surface mass concentration is of primary importance, and the physical and chemical properties of aerosols are of secondary importance. Assessing the uncertainty in the initial and boundary conditions is critical for obtaining accurate predictions of mass concentrations; thus, data assimilation is required. For the purpose of obtaining an operational forecast, together with data assimilation, the computationally efficient bulk equilibrium method is developed, which does not solve aerosol microphysical processes, such as new particle formation, condensation, and coagulation (see sky blue arrows in Fig. 1c in contrast to the red, blue, and pink arrows in Figs. 1a and 1b). Aerosols are categorized into three categories, namely, SUB 
Geosci. Model Dev. Discuss., https://doi.org/10.5194/gmd-2018-128

Manuscript under review for journal Geosci. Model Dev.

Discussion started: 21 June 2018

(c) Author(s) 2018. CC BY 4.0 License.

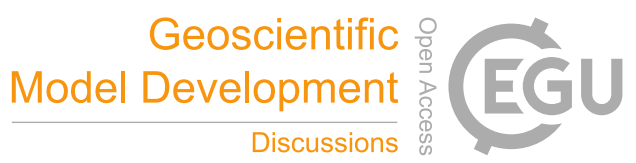

(submicron), DU (dust), and SS (sea-salt). The total dry mass of SUB can be used for the prediction of $\mathrm{PM}_{2.5}$ and the mineral dust mass (denoted as MD) in the DU category. As mentioned earlier in this subsection, thermodynamic equilibrium is assumed for the inorganic components and all of the aerosol-phase components are assumed to exist in SUB, except for $\mathrm{NaNO}_{3}$, which is mixed with sea-salt in the SS category. Most of the $\mathrm{SO}_{4}{ }^{2-}$ and $\mathrm{NH}_{4}{ }^{+}$exist in the submicron size range,

5 whereas $\mathrm{NO}_{3}{ }^{-}$in Japan is usually partitioned into both the submicron and supermicron (or coarse mode) size ranges because the latter is internally mixed with sea-salt or mineral dust particles (Kajino et al., 2012b; Kajino et al., 2013; Uno et al., 2016; Uno et al., 2017). Without considering the coarse mode $\mathrm{NO}_{3}^{-}$, the simulated $\mathrm{PM}_{2.5}$ in East Asia will be significantly overestimated due to the overestimated production of $\mathrm{NH}_{4} \mathrm{NO}_{3}$. Certainly, some of the coarse mode $\mathrm{NO}_{3}{ }^{-}$should be mixed with dust, but the DU category is assumed to be inert in the bulk equilibrium method for the purposes of computational 10 efficiency.

As listed in Table 2, the numbers of the aerosol attributes for the 5-category, 3-category, and bulk equilibrium methods are 50,38, and 20, respectively. Because the triple-moment method is used, the 0th moment (number) and 2nd moment (proportional to surface area) are transported, and the 3rd moment (proportional to volume) is diagnosed based on the mass concentrations of each component and their prescribed densities (i.e., 2.0, 1.77, 2.6, 2.2, 1.83, and $1.0 \mathrm{~g} \mathrm{~cm}^{-3}$ for

15 UID (unidentified mass, or anthropogenic dust), carbonaceous mass (BC and OM), mineral dust (MD), sea-salt (non-volatile components of sea-salt (NS) and $\left.\mathrm{Cl}^{-}\right)$, inorganics $\left(\mathrm{SO}_{4}{ }^{2-}, \mathrm{NO}_{3}{ }_{3}^{-}\right.$, and $\left.\mathrm{NH}_{4}{ }^{+}\right)$, and water $\left(\mathrm{H}_{2} \mathrm{O}\right)$, respectively). Here, note that the NS indicates the non-volatile mass of pure sea-salt particles, namely, the dry sea-salt mass minus the $\mathrm{Cl}^{-}$mass. The rules for the transfer of moments and mass from one category to another due to inter-category coagulation and mode merging are listed in Table 3. The concepts of the inter-category coagulation rules are "from smaller to larger category" for the 3-

20 category and 5-category methods; additionally, the concept of "from hydrophobic to hygroscopic category" and "from nonlight-absorbing to light-absorbing category" are used for the 5-category method. The mode merging represents a transfer of moments and mass, greater than a threshold diameter $(40 \mathrm{~nm})$, due to condensation or self-coagulation growth. During its emission, UID only exists in ACM and DU in the 5-category method, in ACM and COR in the 3-category method, and in SUB and DU in the bulk method. Due to inter-category coagulation, UID is also found in AGR and SS in the 5-category 25 method. Freshly emitted BC only exists in AGR, ACM, and SUB in the 5-category, 3-category, and bulk methods, respectively. The inter-category coagulation transfers $\mathrm{BC}$ in the 5-category method to the $\mathrm{DU}$ and $\mathrm{SS}$ categories and $\mathrm{BC}$ in the 3-category method to COR. OM exists in ATK, ACM, and AGR in the 5-category method, in ATK and ACM in the 3category method, and in SUB in the bulk method during its emission. OM is moved to the DU and SS categories in the 5category method and to COR in the 3-category method. The MD mass only exists in the DU category for the 5-category and bulk methods, and it exists in the COR for the 3-category method. The transfer of the MD mass to the SS category is predicted only in the 5-category method. All of the secondary and semi-volatile components, such as $\mathrm{OM}, \mathrm{SO}_{4}{ }^{2-}, \mathrm{NO}_{3}{ }^{-}, \mathrm{NH}_{4}{ }^{+}$, and $\mathrm{Cl}^{-}$, can exist in all of the categories in the 5-categroy and 3-category methods. They can exist only in SUB in the bulk method, except for $\mathrm{NO}_{3}{ }^{-}$and $\mathrm{Cl}^{-}$, which can mix with sea-salt, as mentioned earlier $\left(\mathrm{Cl}^{-}\right.$also exists in the SS category during emission). All of the aerosol categories can be hygroscopic and thus contain $\mathrm{H}_{2} \mathrm{O}$, except for the DU category of the bulk 
Geosci. Model Dev. Discuss., https://doi.org/10.5194/gmd-2018-128

Manuscript under review for journal Geosci. Model Dev.

Discussion started: 21 June 2018

(c) Author(s) 2018. CC BY 4.0 License.

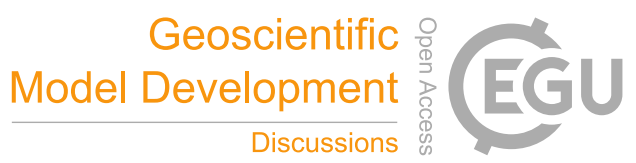

method. As mentioned earlier, crustal cations play an essential role in fixing acidic gases to the aerosol phase. In all three methods, the compositions of the sea-salt and dust particles are defined after Song and Carmichael (2001) as follows: the MD mass contains 6.8, 1.6, 0.91, and $0.78 \mathrm{wt} \%$ of $\mathrm{Ca}^{2+}, \mathrm{Na}^{+}, \mathrm{K}^{+}$, and $\mathrm{Mg}^{2+}$, respectively, and the NS mass contains 68.1 , $17.1,8.21,2.58$, and $2.45 \mathrm{wt} \%$ of $\mathrm{Na}^{+}, \mathrm{SO}_{4}^{2-}, \mathrm{Mg}^{2+}, \mathrm{Ca}^{2+}$, and $\mathrm{K}^{+}$, respectively. It is assumed that the UID mass does not 5 contain any cations and is thus hydrophobic and inert.

In terms of the aerosol water uptake, non-equilibrium treatment is critically important, especially for higher relative humidity conditions and coarse mode particles, because the instantaneous equilibrium assumption can cause unrealistic overestimates of aerosol diameter. For example, the equilibrium diameter of an aerosol with a dry diameter of $1.0 \mu \mathrm{m}$ and a hygroscopicity $\kappa$ value of 1.0 reaches $21.2 \mu \mathrm{m}$ at a relative humidity $\mathrm{RH}=100 \%$ (see $\kappa$-Köhler theory; Petters and

10 Kleidenweis, 2007), which is larger than or as large as the initial sizes of cloud droplets. Under actual atmospheric conditions, aerosols cannot reach such a large equilibrium diameter, either because it takes too long to reach (for low aerosol populations) or because aerosols take too much water vapor from the air, such that the relative humidity becomes substantially lower (for high enough aerosol populations). Therefore, in the 3-category and 5-category non-equilibrium methods, aerosol water uptake is also calculated in a non-equilibrium manner: the mass transfer of water vapor is driven by

15 the differences between the current water content and equilibrium water content, which is derived using the ZSR method (Fountoukis and Nenes, 2007). Note that the RH of air is assumed to remain unchanged due to the water uptake by aerosols. In the bulk equilibrium method, instantaneous equilibrium is assumed for the aerosol water content, but a maximum threshold of ambient $\mathrm{RH}=98 \%$ is used to avoid the abovementioned unrealistically large aerosol size.

The computational costs of the three methods used in the simulations presented in this study are listed in Table 4.

20 The non-equilibrium aerosol microphysics module consumed approximately half of the total CPU time for the 5-category method, while it consumed only $15 \%$ of that of the bulk equilibrium module (and the thermodynamic equilibrium model ISORROPIA2 consumed the major proportion of this $15 \%$ ). The total CPU times of the 3-category and 5-category methods are $44 \%$ and $91 \%$ greater than that of the bulk equilibrium module, respectively. For these three options, the number of gaseous species is the same (58), and the numbers of their aerosol attributes are 20, 38, and 50, respectively.

\subsection{Simulation settings}

Figures 2-10 shows the simulation domain, which covers East Asia with $200 \times 140$ horizontal grid cells with a grid resolution of $\Delta x=30 \mathrm{~km}$. The numbers of the vertical grid cells of NHM and CTM are 38 (reaching up to 22,055 m M.S.L.) and 40 (reaching up to 18,000 m M.S.L.), respectively, with terrain-following coordinates. The analysis period is the entire year of 2006, but two half-year simulations were conducted and then combined, starting from July, with a spin-up period of 305 days. Because climatological data are used for the initial condition of the land surface model (Simple Biosphere Model, $\mathrm{SiB}$ ) of the NHM, July was selected because it exhibited minimum snow coverage during this year in order to avoid the long spin-up period required for the simulated snow cover of the SiB. The JRA-55 global reanalysis (Kobayashi et al., 2015) was used for the initial and boundary conditions of the NHM. Spectral nudging was applied to constrain the simulated 
Geosci. Model Dev. Discuss., https://doi.org/10.5194/gmd-2018-128

Manuscript under review for journal Geosci. Model Dev.

Discussion started: 21 June 2018

(c) Author(s) 2018. CC BY 4.0 License.

meteorological field toward the global analysis, above a height of $7 \mathrm{~km}$ for large-scale wave components (wavelength > $1000 \mathrm{~km}$ ) of horizontal momentum and potential temperature, with a weighting factor of 0.06 (Nakano et al., 2012).

The 3-hourly lateral and upper boundary concentrations of gases and aerosols were obtained from the simulation results of the global models of MRI-CCM2 (Deushi and Shibata, 2011) and MASINGAR-mk2 (Tanaka and Ogi, 2017;

5 Tanaka et al., 2018), respectively. Because the lumped mechanisms of non-methane volatile organic compounds (NMVOC) and aerosol representations of NHM-Chem are different from those of the two global models, only $\mathrm{NO}_{\mathrm{x}}, \mathrm{O}_{3}$, and $\mathrm{CO}$ were taken from the MRI-CCM2, and the total masses of $\mathrm{BC}, \mathrm{OC}, \mathrm{SO}_{4}{ }^{2-}$, mineral dust, and sea-salt were taken from MASINGARmk2 (although this model employs sectional methods for mineral dust and sea-salt). The OM to OC ratio of 1.8 and $100 \%$ existence of $\mathrm{SO}_{4}{ }^{2-}$ as $\left(\mathrm{NH}_{4}\right)_{2} \mathrm{SO}_{4}$ were assumed in the boundary concentrations. The mineral dust and sea-salt were treated as

10 being externally mixed, whereas all of the $\mathrm{BC}, \mathrm{OM}$, and $\left(\mathrm{NH}_{4}\right)_{2} \mathrm{SO}_{4}$ were included in the $\mathrm{ACM}$ in the 3-category method and in the SUB in the bulk equilibrium method. For the 5-category method, $80 \%$ of BC, $\mathrm{OM}$ and $\left(\mathrm{NH}_{4}\right)_{2} \mathrm{SO}_{4}$ were attributed to $\mathrm{ACM}$, and the rest were attributed to AGR.

We used REASv2 (Kurokawa et al., 2009) for the anthropogenic emissions of $\mathrm{NO}_{\mathrm{x}}, \mathrm{SO}_{2}, \mathrm{NH}_{3}, \mathrm{NMVOC}, \mathrm{BC}, \mathrm{POC}$, $\mathrm{PM}_{2.5}$ and $\mathrm{PM}_{10}$ with monthly variations. There is no monthly variation for $\mathrm{NH}_{3}$. Because the REASv2 does not provide 15 hourly and vertical profiles of the emissions, those of Li et al. (2017) were applied to each sector, i.e., power, industry, domestic, transport, aviation, and large point sources. We used the monthly Global Fire Emissions Database (GFED3; Giglio et al., 2010) for open biomass burning emissions $\left(\mathrm{NO}_{\mathrm{x}}, \mathrm{SO}_{2}, \mathrm{NMVOCs}, \mathrm{BC}\right.$, and POC) and the Model of Emissions of Gases and Aerosols from Nature (MEGAN2; Guenther et al., 2006) for biogenic emissions of isoprene, terpenes, methanol, and NO. We applied the monthly mean values of GFED3 without temporal variations. The temporally varying biogenic emission flux

20 was calculated using the surface solar radiation and surface air temperature, as simulated by NHM. Biogenic emissions were allocated to the bottom layer. The open biomass burning emissions were uniformly allocated from the bottom layer up to $1,000 \mathrm{~m}$ above ground level (AGL). An OM to OC ratio of 1.8 was assumed for both the anthropogenic and biomass burning emissions. The $\mathrm{NO}_{\mathrm{x}}$ values in both emissions were partitioned as $90 \% \mathrm{NO}$ and $10 \% \mathrm{NO}_{2}$. In both emissions, $5 \%$ of $\mathrm{SO}_{2}$ emissions were regarded as $\mathrm{SO}_{4}{ }^{2-}$. REASv2 provided speciation information about NMVOC, which was redistributed to the 25 NMVOC speciation of SAPRC99. When a SAPRC99 speciation was finer than that of REASv2, the speciated NMVOC of REASv2 was equally distributed to that of SAPRC99 with equal mixing ratios. Because GFEDv3 does not provide NMVOC speciation information, that of Woo et al. (2003) was applied and allocated to the SAPRC99 speciation. The UID emissions of the fine and coarse modes were defined as $\mathrm{PM}_{2.5}$ minus BC minus POM (primary organic mass; $1.8 \times$ POC) and $\mathrm{PM}_{10}$ minus $\mathrm{PM}_{2.5}$, respectively. The $\mathrm{SO}_{4}{ }^{2-}$ emissions were distributed as $10 \%$ and $90 \%$ in ATK and ACM, respectively, for the 5-

30 category and 3-category methods. A total of 5\%, 10\%, and $85 \%$ of POM emissions were distributed to ATK, AGR, and $\mathrm{ACM}$ in the 5-category method, whereas $5 \%$ and $95 \%$ of these emissions were distributed to ATM and ACM, respectively.

Hourly volcanic $\mathrm{SO}_{2}$ emissions in Japan were developed in this study. These emissions were assumed to comprise $100 \% \mathrm{SO}_{2}$, and no volcanic $\mathrm{SO}_{4}{ }^{2-}$ emissions were considered. JMA regularly monitored the $\mathrm{SO}_{2}$ emission fluxes and smoke heights of the five major volcanoes in Japan. The cubic spline interpolation was applied over time to obtain hourly data, as 
Geosci. Model Dev. Discuss., https://doi.org/10.5194/gmd-2018-128

Manuscript under review for journal Geosci. Model Dev.

Discussion started: 21 June 2018

(c) Author(s) 2018. CC BY 4.0 License.

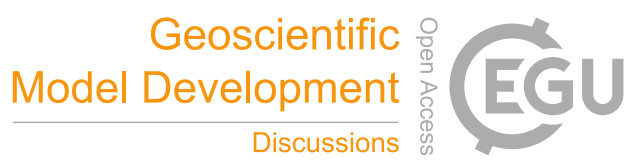

done by Kajino et al. (2004). The locations and period of the volcanic data are summarized in Table 5. The time series of the smoothed volcanic emissions, together with the raw data, are illustrated in Supplement 1. The volcanic emissions from other volcanoes in the world are taken from Andres and Kasgnoc (1998). The volcanic emissions were uniformly allocated from the bottom layer to the smoke height or to 1,000 m AGL when smoke height information was not available.

The methods of Han et al. (2004) and Clarke et al. (2006) were used to predict the emissions of mineral dust and sea-salt particles as functions of the friction velocity and 10-m wind speed, respectively. In addition to the formula of Han et al. (2004), the simulated snow coverage was applied to reduce the emission flux. Flux adjustments were made for the mineral dust and sea-salt emissions by using the observed non-sea-salt (nss)-Ca ${ }^{2+}$ (defined in Sect. 3) and $\mathrm{PM}_{10}$ values for mineral dust and the observed $\mathrm{Na}^{+}$and $\mathrm{PM}_{10}$ values for sea-salt, obtained at the seven Japanese Acid Deposition Monitoring

10 Network in East Asia (EANET) stations. The adjustment ratios of the dust and sea-salt emission fluxes in the simulations were 0.5 and 0.3 , respectively.

The acronyms for the aerosol parameters used in this study are summarized in Table 6. Aerosol sizes should be carefully defined because both their physical and optical measures significantly vary depending on whether their diameters are number-equivalent or mass-equivalent, wet or dry, and actual or aerodynamic. The width of the distribution $\sigma_{\mathrm{g}}$,

15 hygroscopicity $\kappa$, and aerosol density $\rho_{p}$ are also key parameters because they affect the magnitudes of their physical and optical measures. Certainly, shape factors can also significantly affect these measures, as well as aerosol microphysical processes; however, all of the modeled particles are assumed to be spherical in the current version of NHM-Chem, as they are in most other CTMs.

Both Han et al. (2004) and Clarke et al. (2006) provided size-resolved emission fluxes, whereas this model assumes a log-normal size distribution. The size distribution of mineral dust was fitted by using a prescribed value of $\sigma_{\mathrm{g}}=2.0$ and number-equivalent dry $D_{\mathrm{g}}\left(D_{\mathrm{g}, \mathrm{n}, \mathrm{dry}}\right)$ values of $0.66,1.22$, and $1.22 \mu \mathrm{m}$ for the LUC of desert, loess, and grass, respectively. For a reference, $D_{\mathrm{g}, \mathrm{n}, \mathrm{dry}}$ values of 0.66 and $1.22 \mu \mathrm{m}$ correspond to aerodynamic $D_{\mathrm{g}, \mathrm{n}, \mathrm{dry}}\left(D_{\mathrm{g}, \mathrm{n}, \text { aero,dry }}\right)$ values of 1.06 and $1.96 \mu \mathrm{m}$, mass-equivalent dry aerodynamic $D_{\mathrm{g}}\left(D_{\mathrm{g}, \mathrm{m}, \text { aero,dry }}\right)$ values of 4.50 and $8.31 \mu \mathrm{m}$, and $\mathrm{PM}_{2.5} / \mathrm{PM}_{10}$ ratios of 0.23 and 0.068 , respectively. Note that here, the simulated $\mathrm{PM}_{\mathrm{x}}$ was derived as a proportion of the dry mass in which the aerodynamic ambient (wet) diameter was exactly smaller than $x \mu \mathrm{m}$, as follows:

The simulated $\mathrm{PM}_{\mathrm{x}}$ can be calculated using the error function (erf) as follows:

$$
\mathrm{PM}_{x}=\sum_{i} \frac{M_{i}}{2} \operatorname{erf}\left(\frac{\ln D_{x}-\ln D_{g, m, \text { aero }, i}}{\sqrt{2} \ln \sigma_{g, i}}\right)
$$

where $i$ and $M_{i}$ indicate the category and dry mass of the category, respectively.

Because Clarke et al. (2006) proposed tri-modal size distributions, they needed to be combined into a single mode. Laboratory and field experiments indicated that the major proportions of the smallest mode (i.e., $10-132 \mathrm{~nm}$ ) should be 
Geosci. Model Dev. Discuss., https://doi.org/10.5194/gmd-2018-128

Manuscript under review for journal Geosci. Model Dev.

Discussion started: 21 June 2018

(c) Author(s) 2018. CC BY 4.0 License.

sea-salt emissions in this model. The number and volume fluxes of the sea-salt emission flux were obtained as the summations of those of the second-largest and largest modes. The surface area flux was then deduced based on the number, volume, and prescribed value of $\sigma_{\mathrm{g}}=2.0$. The $D_{\mathrm{g}, \mathrm{n}, \text { aero,dry }}$ value, $D_{\mathrm{g}, \mathrm{m} \text {,aero,dry }}$ value, and $\mathrm{PM}_{2.5} / \mathrm{PM}_{10}$ ratio of dry sea-salt particles are $0.448 \mu \mathrm{m}, 1.89 \mu \mathrm{m}$, and 0.66 , respectively. Because sea-salt particles are highly hygroscopic, at conditions of $\mathrm{RH}=80 \%$

5 and $90 \%$, the ambient diameter $D_{\mathrm{g}, \mathrm{m}, \text { aero }}$ values would be 2.39 and $2.88 \mu \mathrm{m}$ and the $\mathrm{PM}_{2.5} / \mathrm{PM}_{10}$ ratios would be 0.54 and 0.44 , respectively, assuming a hygroscopicity value of $\kappa=1.0$.

The prescribed size parameters were applied to the emissions of all species, except for mineral dust and sea-salt, and are defined as follows: $\left(D_{\mathrm{g}, \mathrm{n}, \mathrm{aero}, \mathrm{dry}}, \sigma_{\mathrm{g}}\right)=(0.01 \mu \mathrm{m}, 1.3),(0.1 \mu \mathrm{m}, 1.5),(0.1 \mu \mathrm{m}, 1.5)$, and $(2 \mu \mathrm{m}, 1.8)$ for the ATK, ACM, AGR, and DU (applied to anthropogenic dust only, denoted as UID) categories of the 5-category method; $(0.01 \mu \mathrm{m}, 1.3)$,

$10(0.1 \mu \mathrm{m}, 1.5)$, and $(2 \mu \mathrm{m}, 1.8)$ for the ATK, ACM, and COR (applied to UID only) categories of the 3-category method; and $(0.1 \mu \mathrm{m}, 1.5)$ and $(2 \mu \mathrm{m}, 1.8)$ for the SUB and DU (applied to UID only) categories of the bulk equilibrium method, respectively.

Although the global model has its own size distributions of aerosols, the prescribed size parameters were applied to the lateral and upper boundary concentrations of NHM-Chem, which are defined as follows: $\left(D_{\mathrm{g}, \mathrm{n}, \mathrm{aero}, \mathrm{dry}}, \sigma_{\mathrm{g}}\right)=(0.01 \mu \mathrm{m}, 1.3)$,

$15(0.1 \mu \mathrm{m}, 1.5),(0.1 \mu \mathrm{m}, 1.5),(2 \mu \mathrm{m}, 1.8)$, and $(1 \mu \mathrm{m}, 1.8)$ for the ATK, ACM, AGR, DU and SS categories of the 5-category method; $(0.01 \mu \mathrm{m}, 1.3),(0.1 \mu \mathrm{m}, 1.5)$, and $(1 \mu \mathrm{m}, 1.8)$ for the ATK, ACM, and COR (mineral dust and sea-salt) categories of the 3-category method; and $(0.1 \mu \mathrm{m}, 1.5),(2 \mu \mathrm{m}, 1.8)$, and $(1 \mu \mathrm{m}, 1.8)$ for the SUB, DU, and SS categories of the bulk method, respectively. Certainly, in the self-nesting simulations, where the boundary concentrations are taken from the outer domain simulation of NHM-Chem, the prescribed size parameters are not needed.

\section{Model performances for various purposes}

In this section, the inter-module comparisons between the bulk equilibrium, 3-category, and 5-category methods are presented in terms of their relevant purposes, operational forecast, air quality forecast, and forecast of climate-relevant variables of aerosols, respectively.

\subsection{Operational forecast $\left(\mathrm{O}_{3}\right.$, mineral dust, and $\left.\mathrm{PM}_{2.5}\right)$}

25 Figures 2-4 present the seasonal mean surface concentrations of $\mathrm{O}_{3}$, mineral dust, and $\mathrm{PM}_{2.5}$, respectively, to show the performance of the bulk method relative to that of a reference method, i.e., the 5-category method, in the predictions of the mass concentrations of components that are often used in operational air quality forecasts.

The mid-latitude westerly is predominant in this region, and air pollutants are transported from west (or northwest) to east (or southeast) associated with migrating disturbances, including the cold and warm frontal transports of cyclones and

30 anticyclonic transport throughout the year except during summer. In summer, due to the Pacific high system, the transport of continental air masses is less dominant, and clean air masses of maritime origin are often transported to Japan. Northerly to 
Geosci. Model Dev. Discuss., https://doi.org/10.5194/gmd-2018-128

Manuscript under review for journal Geosci. Model Dev.

Discussion started: 21 June 2018

(c) Author(s) 2018. CC BY 4.0 License.

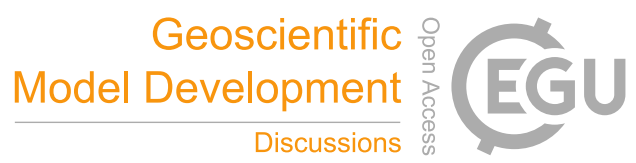

northwesterly wind prevails in winter due to the Siberian high system. These seasonal wind patterns can be clearly observed in the figures.

The simulated seasonal mean surface $\mathrm{O}_{3}$ concentration was highest in the summer in the emission source region but highest in the spring in Japan (Fig. 2). The difference between the two methods was very small. The bulk- $\mathrm{O}_{3}$ was generally

5 larger than the 5-category- $\mathrm{O}_{3}$, which was mainly due to differences in the heterogeneous reactions because the simulated aerosol surface area concentration of the bulk method was generally larger that of the 5-category method. Because the bulk method does not resolve the microphysical processes of aerosols, it is nonsensical to discuss the differences in surface area concentrations; however, the overestimation by the bulk method was larger in regions further downwind by up to $5 \%$. Because this difference is minor compared to the difference between the simulation and observation, improving the model

10 processes and/or boundary conditions will certainly improve all of the simulation results, regardless of the aerosol category methods that are selected.

The simulated surface mineral dust concentration was highest in the spring in the emission source regions (Taklamakan and Gobi) as well as in the downwind regions, Korea, and Japan (Fig. 3). The differences between the bulk and 5 -category methods were generally lower than $5 \%$ and at most up to $10 \%$. This difference could be due mainly to differences

15 in the chemical aging of mineral dust, which increases in hygroscopicity due to condensational growth during its long-range transport in the 5-category method. This is not related to an operational forecast issue, but there are more significant differences found between the 3-category and 5-category methods. The 3-category and 5-category methods both consider chemical aging processes, but the 3-category method assumes a complete internal mixture of dust and sea-salt. Accordingly, in the 3-category method, the dust particles were more hygroscopic but smaller, so that the surface air concentration was

20 higher over the ocean in the spring by up to $10 \%$ due to their lower gravitational and dry deposition velocities compared to those in the 5-category method case. The 3-category to 5-category dust concentration ratio was higher in the regions on the continent close to the west lateral boundary due to the difference in the sizes of dust; additionally, a complete dust/sea-salt mixture was assumed in the boundary of the 3-category method. Because this difference is minor compared to the difference between the simulation and observation, improving the model processes and/or boundary conditions will certainly improve all of the simulation results regardless of the aerosol category methods that are selected.

The differences in the model performance of the $\mathrm{PM}_{2.5}$ prediction are shown in Fig. 4. This $\mathrm{PM}_{2.5}$ was derived by Eq. 1, but the simulated $\mathrm{PM}_{2.5}$ was sometimes defined as the pile-up of the mass concentrations of the dry components existing in the submicron categories, which is independent from the aerosol size distribution. The latter is denoted as $\mathrm{PM}_{2.5}$ (pile-up) in the manuscript, and these data are shown in Supplement 2. The major difference between the simulated $\mathrm{PM}_{2.5}$ and $\mathrm{PM}_{2.5}$ (pile-up) is that $\mathrm{PM}_{2.5}$ includes some proportions of natural aerosols, such as sea-salt and dust, and it can exclude proportions of submicron categories (i.e., ACM and AGR) larger than $2.5 \mu \mathrm{m}$, whereas $\mathrm{PM}_{2.5}$ (pile-up) completely excludes sea-salt and dust particles and includes all submicron categories. The simulated $\mathrm{PM}_{2.5}$ concentration was highest in the winter in the emission source region due to its higher emissions and more stable stratification, whereas it was highest in the spring in Japan (Fig. 4). The 3-category $\mathrm{PM}_{2.5}$ was lower than the bulk-PM 2.5 but generally higher than the 5-category $\mathrm{PM}_{2.5}$. Both the 
Geosci. Model Dev. Discuss., https://doi.org/10.5194/gmd-2018-128

Manuscript under review for journal Geosci. Model Dev.

Discussion started: 21 June 2018

(c) Author(s) 2018. CC BY 4.0 License.

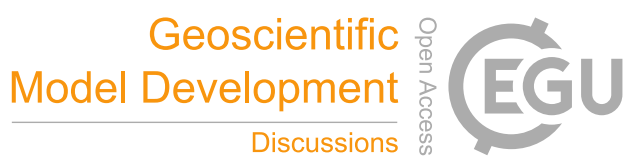

(c) (i)

bulk- $\mathrm{PM}_{2.5}$ and 3-category- $\mathrm{PM}_{2.5}$ were larger than the 5-category- $\mathrm{PM}_{2.5}$, but for different reasons. The overestimation of bulk- $\mathrm{PM}_{2.5}$ was mainly due to the overestimation of submicron $\mathrm{NO}_{3}^{-}$, whereas that of 3-category- $\mathrm{PM}_{2.5}$ was mainly due to the assumption of a complete internal dust/sea-salt mixture. As found in Fig. S2-1, the overestimation of the bulk to 5-category ratio of $\mathrm{PM}_{2.5}$ (pile-up) was consistent with that of $\mathrm{PM}_{2.5}$ due to the same reason (i.e., the overestimation of submicron $\mathrm{NO}_{3}{ }^{-}$).

5 In contrast, the 3-category to 5-category ratio of $\mathrm{PM}_{2.5}$ (pile-up) was very small, indicating that the internal dust/sea-salt mixture assumption has almost no impact on the dry mass concentration of the submicron categories. Table S2 shows that the Sim:Obs of $\mathrm{PM}_{2.5}$ was greater than that of $\mathrm{PM}_{2.5}$ (pile-up), indicating that approximately $20 \%$ of sea-salt (and $40 \%$ of the dust/sea-salt mixture) contributed to $\mathrm{PM}_{2.5}$ at Oki and Rishiri. It is hard to say if the bulk method is eligible for the operational forecast because the bulk- $\mathrm{PM}_{2.5}$ was generally larger than the 3- and 5-cateogry- $\mathrm{PM}_{2.5}$ by approximately 20-

$10100 \%$. Although they have not yet been discussed, there are still large discrepancies in the simulated and observed $\mathrm{PM}_{2.5}$ chemical compositions in Japan. Because the uncertainties in both the simulated chemical compositions and their size distributions contribute to the simulated $\mathrm{PM}_{2.5}$, it is not necessary for the 5-category method to yield the best prediction of $\mathrm{PM}_{2.5}$. In fact, the $R$ value of the bulk- $\mathrm{PM}_{2.5}$ was better than those of both the $\mathrm{PM}_{2.5}$ and $\mathrm{PM}_{2.5}$ (pile-up) of the 3- and 5category methods (Kajino et al., 2018a and Fig. S4). However, the current analysis is insufficient to evaluate the eligibility of

15 the model in the $\mathrm{PM}_{2.5}$ operational forecast because the simulated $\mathrm{PM}_{2.5}$ was compared with observations obtained at only two stations on remote islands. Currently, relevant work is ongoing under the framework of a multimodel inter-comparison study project of Japan called J-STREAM (Chatani et al., 2018).

\subsection{Air quality issues (mass concentration and deposition)}

$20 \mathrm{PM}_{2.5}$ is an issue of air quality, but it was discussed in the previous "operational forecast" subsection, which showed that the seasonal average $\mathrm{PM}_{2.5}$ surface mass concentration could vary by approximately 20-100\%. Figs. 5 and 6 compare the predictions of the dry and wet depositions of the inorganic components of $\mathrm{SO}_{4}{ }^{2-}, \mathrm{T}_{-} \mathrm{NH}_{4}{ }^{+}$, and $\mathrm{T}_{-} \mathrm{NO}_{3}{ }^{-}$, which are the major acidic and basic substances, obtained using the three methods. Once deposited to the ground surface, $\mathrm{NH}_{4}{ }^{+}$is efficiently converted to $\mathrm{NO}_{3}{ }^{-}$in the soil; thus, $\mathrm{NH}_{4}{ }^{+}$is also an important agent for environmental acidification. The horizontal distribution of dry deposition was generally similar to that of surface air concentration because the dry deposition flux is proportional to the surface air concentration. The dry depositions (Fig. 5) of the 3-category and 5-category methods were very similar to each other (the difference was lower than $5 \%$ in most of the domain) because the size distribution and gasaerosol partitioning of the components were similar. The separation of soot/soot-free and dust/sea-salt in the 5 -category method did not substantially alter the size or gas-aerosol partitioning.

The difference between the bulk and 5-category methods was significantly different and varied by up to a factor of two. This difference is mainly due to the gas-aerosol partitioning of $\mathrm{T}_{-} \mathrm{NO}_{3}{ }^{-}$. The differences between $\mathrm{SO}_{4}{ }^{2-}$ and $\mathrm{NH}_{4}^{+}$ obtained using different methods were less significant. The dry deposition of $\mathrm{T}_{-} \mathrm{NO}_{3}{ }^{-}$of the bulk method was smaller over land, because no coarse mode $\mathrm{NO}_{3}{ }^{-}$was formed over land (see $\mathrm{T}^{-\mathrm{NO}_{3}}{ }^{-}$at Qingdao of Fig. 12 of Kajino et al., 2018a), where 
Geosci. Model Dev. Discuss., https://doi.org/10.5194/gmd-2018-128

Manuscript under review for journal Geosci. Model Dev.

Discussion started: 21 June 2018

(c) Author(s) 2018. CC BY 4.0 License.

its dry deposition velocity is much larger than that of submicron $\mathrm{NO}_{3}{ }^{-}$. Consequently, compared to the other two methods, the total (i.e., $\mathrm{SO}_{4}{ }^{2-}, \mathrm{T}-\mathrm{NH}_{4}{ }^{+}$, plus $\mathrm{T}-\mathrm{NO}_{3}{ }^{-}$) dry deposition flux of the bulk method over land was smaller. $\mathrm{The}^{-} \mathrm{HNO}_{3}$ gas concentration of the bulk method was generally larger than those of the 3- and 5-category methods because the bulk method contained fewer counterpart ions of $\mathrm{NO}_{3}{ }^{-}$(i.e., mineral dust) than the other two methods (see $\mathrm{T}_{-} \mathrm{NO}_{3}{ }^{-}$at Hedo of Fig. 12 of

5 Kajino et al., 2018a). Therefore, the dry deposition amount of $\mathrm{HNO}_{3}$ gas (and so the total amount) of the bulk method was larger than the other two methods especially over the ocean, where the dry deposition velocity of $\mathrm{HNO}_{3}$ gas was much faster than that of aerosols, as discussed in Sect. 4.1 of Kajino et al., 2018a.

The horizontal distribution of the wet deposition flux is patchier than that of the dry deposition flux, but similar patterns were found for both fluxes (Fig. 6). The difference in the fluxes between the 3-category and 5-category methods was

10 small (lower than $10-20 \%$ in most of the domain) but more significant than the difference of the dry deposition fluxes. The wet deposition of the 3-category method was generally larger than that of the 5-category method due to the overestimation of wet deposition of $\mathrm{SO}_{4}{ }^{2-}, \mathrm{NH}_{4}{ }^{+}$, and $\mathrm{NO}_{3}{ }^{-}$mixed with $\mathrm{BC}$ as discussed later in Sect. 3.4.

\subsection{Climate-relevant indices: indications for aerosol-radiation interactions}

Figures 7 and 8 compare the three methods in terms of their predictions of aerosol optical thickness (AOT) and absorbing $15 \mathrm{AOT}$ (AAOT) at a wavelength of $500 \mathrm{~nm}$ integrated from the ground surface up to approximately $1 \mathrm{~km} \mathrm{AGL}$, respectively.

The Mie theory calculation was performed to derive the AOT and AAOT at wavelengths of $500 \mathrm{~nm}$ by using simulated log-normal size distribution parameters and chemical compositions. The refractive indices of the Optical Properties of Aerosols and Clouds (OPAC) database (Hess et al., 1998) were used for the Mie calculation. For the refractive indices of the model components of UID, $\mathrm{BC}, \mathrm{OM}, \mathrm{MD}, \mathrm{NS}, \mathrm{SO}_{4}{ }^{2-}, \mathrm{NH}_{4}{ }^{+}, \mathrm{NO}_{3}{ }^{-}, \mathrm{Cl}^{-}$, and $\mathrm{H}_{2} \mathrm{O}$, the database of values of

“insoluble", "soot”, “insoluble", “mineral”, "sea-salt”, "water-soluble”, “water-soluble”, "water-soluble", "sea-salt”, and "fog", respectively, were used, with some modifications for BC to $1.85-0.71 i$ (Bond et al., 2006) and MD to $1.5-0.001 i$ (Aoki et al., 2005) at $500 \mathrm{~nm}$. To calculate the optical properties of light-non-absorbing and light-absorbing mixtures, the Maxwell-Garnett approximation was used. The $\mathrm{BC}$ and MD masses were regarded as light-absorbing components, and the others were regarded as non-light-absorbing (certainly, some proportions of OM are light-absorbing, i.e., Brown Carbon, but they are not considered in the current model). The volume-weighted refractive indices were used for the light-absorbing and non-light-absorbing parts of particles in each category.

Because the bulk method was not designed for climate modeling, it is nonsensical to show its results. It is only noted here that using different assumptions of size and mixing state could cause significant differences in the AOT simulation (up to a factor of two), even though their total mass burdens were not very different. In terms of the comparison between the 3-category and 5-category methods, the 3-category-AOT was larger by 20-100\% near the west and north boundaries, where the AOT was small $(<0.1)$. This increase was due to differences in the internal/external mixture assumptions of soot/soot-free and dust/sea-salt at the boundaries. In the large emission source regions and their downwind regions, the differences in AOT between the 3-category and 5-category methods were small, i.e., smaller than 10\% in most 
Geosci. Model Dev. Discuss., https://doi.org/10.5194/gmd-2018-128

Manuscript under review for journal Geosci. Model Dev.

Discussion started: 21 June 2018

(c) Author(s) 2018. CC BY 4.0 License.

of the domain and the seasons. In Fig. 8, the 3-category-AAOT was significantly larger over the regions under the influence of the west and north boundaries, and the AAOT was small $(<0.01)$. This was due to the overestimation of the so-called lensing effect (i.e., absorption enhancement by a light-absorbing agent coated by a non-light-absorbing agent; e.g., Bond et al., 2006) by the 3-category method at its boundaries, as all soot particles are coated by soot-free particles. This enhancement

5 in AAOT was also observed inside the model domain, over the large emission source and their downwind regions, but the overestimation was small (up to $10 \%$ ). On the other hand, the internal mixture assumption of the 3-category method caused the overestimation of the wet scavenging rates of soot and dust because the soot/soot-free and dust/sea-salt mixture assumption could make the soot and dust particles larger and more hygroscopic. Consequently, the AAOT of the 3-category method was sometimes smaller than that of the 5-category method over the downwind regions, but this difference was also

10 small (up to 10\%). Fig. 9 shows the total (dry + wet) deposition of BC and the differences between the 3- and 5-category methods. Because the dry deposition velocity of $\mathrm{BC}$ is very small, most $\mathrm{BC}$ deposition occurred due to wet deposition processes (which is also obvious from its patchy features). This difference was smaller in the spring and summer (reaching overestimation values of up to $10 \%$ ) and largest in the winter (20-100\%) due to the internal mixture assumption of soot and soot-free particles. Overestimation of the 3-category AAOT was more pronounced in the spring and summer than that in the

15 winter (Fig. 8), because condensation of secondary aerosols to $\mathrm{BC}$ was larger in the warmer seasons and because overestimation of the 3-category wet deposition of $\mathrm{BC}$ was more significant in the winter (Fig. 9). The differences in the total deposition of mineral dust between the 3 - and 5-category methods were very small.

\subsection{Climate-relevant indices: indications for aerosol-cloud interactions}

The horizontal distributions of the averaged $\mathrm{CCN}$ at a supersaturation value of $0.1 \%$ below approximately $1 \mathrm{~km}$ AGL are

20 compared in Fig. 10. Whereas the differences of the total CCN between the two methods were very small (up to $10 \%$ ), significant differences were observed for some components and occasions of CCN. Figs. $11-14$ illustrate the scatter diagrams of the simulated daily mean, averaged-below-1 km-AGL, CCN concentrations (of the 3- and 5-category methods and at supersaturations of $0.1 \%$ and $1 \%$ ) and mass concentrations of all model grids, excluding 10 grids from the four lateral boundaries for the year 2006. The number of points in the scatter diagrams were randomly reduced to one-twentieth of their value in order to avoid too many overlaps of symbols. The two supersaturation levels of $0.1 \%$ and $1 \%$ were used for this evaluation as the typical ranges of stratiform and convective clouds (Seinfeld and Pandis, 2006).

Figure 11 shows the relationship between the total CCN and the sea-salt mass over the ocean. In the meteorological models, the $\mathrm{CCN}$ spectra (i.e., the relationship between supersaturation and $\mathrm{CCN}$ ) were often prescribed and the $\mathrm{CCN}$ over the ocean was often assumed to be one order of magnitude lower than that over the land (e.g., Rasmussen et al., 2002).

30 However, as the ocean regions in the model domain were located downwind of the large emission source regions, $\mathrm{CCN}$ could be as large as that over the land (e.g., Koike et al., 2012). The simulated total CCN over the ocean areas was up to two orders of magnitude larger than that of sea-salt particles for both $0.1 \%$ and $1 \%$. The $\mathrm{CCN}$ at $1 \%$ was one order of magnitude larger than that at $0.1 \%$. The $\mathrm{CCN}$ over the ocean was not correlated against the sea-salt mass concentration. The $\mathrm{CCN}$ was 
Geosci. Model Dev. Discuss., https://doi.org/10.5194/gmd-2018-128

Manuscript under review for journal Geosci. Model Dev.

Discussion started: 21 June 2018

(c) Author(s) 2018. CC BY 4.0 License.

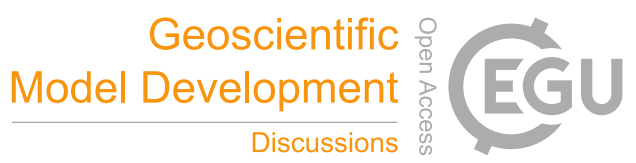

rather proportional to the $\mathrm{SO}_{4}{ }^{2-}$ concentrations, an indicator of anthropogenic secondary particles. These results indicated the importance of predictions of $\mathrm{CCN}$ in the meteorological models. The difference between the two methods was small, such that the difference in the impact of changes in the $\mathrm{CCN}$ on clouds and precipitation over the ocean could also be small.

Figure 12 shows the differences in $\mathrm{CCN}$ over land. The submicron $\mathrm{CCN}$ at $1 \%$ was one order of magnitude larger

5 than that at $0.1 \%$. The difference in supermicron $\mathrm{CCN}$ between $0.1 \%$ and $1 \%$ was not very significant because the larger size particles are $\mathrm{CCN}$ active at lower supersaturation. There was no difference for hygroscopic sea-salt particles, whereas there was a slight difference for less hygroscopic dust particles. Due to the internal mixture assumption of soot and soot-free particles, the $\mathrm{CCN}$ at $0.1 \%$ of the 3-category method was slightly larger than that of the 5-category method. If the model assumes a constant size distribution of submicron particles, all of the points are aligned on a single line. Thus, the width of

10 the aggregations of points indicates the uncertainty or variability of the simulated size distribution of aerosols. The CCN at $0.1 \%$ can vary by approximately 2-fold (e.g., it ranges from $3-6 \times 10^{3} \mathrm{~cm}^{-3}$ at $100 \mu \mathrm{g} \mathrm{m}^{-3}$ of aerosol mass). The variation (or width) was even much larger at $1 \%$, reaching up to approximately 1 order of magnitude $\left(5-80 \times 10^{3} \mathrm{~cm}^{-3}\right.$ at $\left.50 \mu \mathrm{g} \mathrm{m}^{-3}\right)$ because more smaller particles can be activated, which contribute less to the bulk mass concentration. The accurate prediction of aerosol population is much more important for $\mathrm{CCN}$ at higher supersaturation values. There are apparent

15 differences in the slopes of mineral dust and sea-salt in both methods. However, there is one more intermediate slope in the 3-category method, which is the result of the unrealistic internal mixture of dust and sea-salt. Overall, it is safe to presume that the difference in the impact of changes in $\mathrm{CCN}$ on clouds and precipitation over the land between these two methods could also be small.

Figure 13 illustrates the relationship between mineral dust containing $\mathrm{CCN}$ and the mineral dust mass. Because dust is assumed to be inert and $\kappa$ is assumed to be zero in the bulk method, the $\mathrm{CCN}$ at $0.1 \%$ is only proportional to the mineral dust mass concentration, while the variation in the size distribution become more important for $\mathrm{CCN}$ at $1 \%$. Because the hygroscopic growth of mineral dust was considered in the 5-category method, the dust containing CCN becomes up to several times larger than that of the bulk method (from 0.1 to $0.4 \times 10^{2} \mathrm{~cm}^{-3}$ at $600 \mu \mathrm{g} \mathrm{m}^{-3}$ ). As previously mentioned, the unrealistic internal mixture of dust and sea-salt in the 3-category method caused unrealistic slopes, i.e., one that is colored in red (sea-salt with tiny dust mass) and a slope in between (approximately at $x=600 \mu \mathrm{g} \mathrm{m}^{-3}$ and $y=2.510^{2} \mathrm{~cm}^{-3}$ ) that can be clearly seen at $1 \%$ (sea-salt/dust mixture). The simulated difference in dust containing CCN would have almost no impacts on $\mathrm{CCN}$ - cloud - precipitation interaction processes because its number was too small compared to that of submicron particles. As mineral dust is an efficient IN (e.g., Lohmann and Diehl, 2006), it should be noted here that this difference can have significant impacts on IN - cloud - precipitation interaction processes, especially with immersion and condensation freezing (i.e., the freezing of super-cooled water droplets containing ice nuclei).

Despite the external mixture treatment of soot and soot-free particles in the 5-category method, the difference in the total submicron $\mathrm{CCN}$ between the 5- and 3-category methods was found to be minor (Fig. 12). However, the simulated BCcontaining CCN values of the two methods were different, as is shown in Fig. 14. The BC-containing CCN of the 3-category method at $0.1 \%$ was generally 1.5 times larger than that of the 5-category method (e.g., up to 9 and $6 \times 10^{3} \mathrm{~cm}^{-3}$ at $5 \mu \mathrm{g} \mathrm{m}^{-3}$, 
Geosci. Model Dev. Discuss., https://doi.org/10.5194/gmd-2018-128

Manuscript under review for journal Geosci. Model Dev.

Discussion started: 21 June 2018

(c) Author(s) 2018. CC BY 4.0 License.

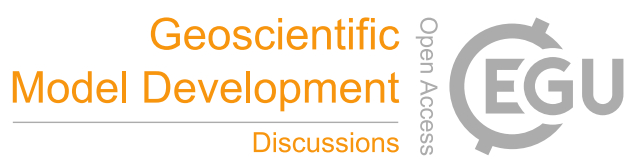

(c) (i)

respectively) because the absence of $\mathrm{BC}$-free particles cause excess amounts of coatings on BC-containing particles (Oshima et al., 2009b). This difference caused higher BC deposition to be simulated by the 3-category method, as presented in Fig. 9. However, the difference in the $\mathrm{BC}$-containing $\mathrm{CCN}$ of the two methods at $1 \%$ was not as large because the $\mathrm{CCN}$ number at higher supersaturation is not affected by hygroscopicity.

\section{Conclusion}

A regional-scale meteorology - chemistry model (NHM-Chem) was developed. The variety of aerosol category representations is a unique feature of NHM-Chem. Currently, three options are available: 5-category non-equilibrium (Aitken, soot-free accumulation, soot-containing accumulation, sea-salt, and dust), 3-category non-equilibrium (Aitken, accumulation, and coarse), and bulk equilibrium (submicron, sea-salt, and dust) methods. These three methods were

10 designed for different purposes, namely, regional climate modeling including aerosol-cloud-radiation interactions, air quality modeling, and operational forecasts, respectively. The number of tracers in the 5-category, 3-category, and bulk methods are 108, 96, and 78, respectively (they each contain 58 common gases and 50, 38, and 20 aerosol attributes, respectively). The total CPU times of the 5-category and 3-category methods were $91 \%$ and $44 \%$ greater than that of the bulk method, respectively.

The bulk equilibrium method was shown to be eligible for operational forecast purposes, namely, the surface mass concentrations of air pollutants such as $\mathrm{O}_{3}$, mineral dust, and $\mathrm{PM}_{2.5}$. The differences in the simulated seasonal mean concentrations between the bulk method and the reference method, i.e., the 5 -category method, were smaller than $5 \%$ and 5 $10 \%$ for $\mathrm{O}_{3}$ and mineral dust, respectively. The initial and boundary conditions should be improved before model formulations. The difference in $\mathrm{PM}_{2.5}$ was larger, i.e., up to $20-100 \%$. Improving the model formulation, as well as its initial and boundary conditions, is needed.

The 3-category method was shown to be eligible for air quality simulations, namely, mass concentrations and depositions. The differences in the simulated seasonal mean bulk mass concentrations $\left(\mathrm{PM}_{2.5}\right.$ (pile-up)) and dry and wet depositions of major inorganic components $\left(\mathrm{SO}_{4}{ }^{2-}+\mathrm{NH}_{4}{ }^{+}+\mathrm{NO}_{3}{ }^{-}\right)$between the 3-category method and the reference method were smaller than $5 \%, 5 \%$, and $10 \%$, respectively. However, the internal mixture assumption of soot/soot-free and dust/sea-

25 salt particles in the 3-category method resulted in significant differences in the size distribution and hygroscopicity of the particles. The differences in $\mathrm{PM}_{2.5}$, defined by the simulated size distribution, between the 3- and 5-category methods reached up to $20-100 \%$.

Even though the 3-category method was not designed to simulate aerosol-cloud-radiation interaction processes, its performance in terms of bulk properties, such as AOT and CCN, was acceptable compared to that of the reference method 30 (i.e., both differences were smaller than 10\%). However, some specific parameters exhibited significant differences or systematic errors. The unrealistic dust/sea-salt complete mixture of the 3-category method induced significant errors in the prediction of mineral dust containing $\mathrm{CCN}$. The overestimation of soot hygroscopicity by the 3-category method induced 
Geosci. Model Dev. Discuss., https://doi.org/10.5194/gmd-2018-128

Manuscript under review for journal Geosci. Model Dev.

Discussion started: 21 June 2018

(c) Author(s) 2018. CC BY 4.0 License.

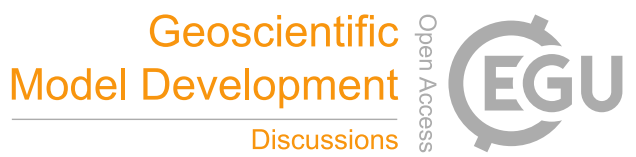

(c) (i)

errors in $\mathrm{BC}$-containing $\mathrm{CCN}$ at a supersaturation of $0.1 \%$ (overestimation by $\sim 50 \%$ ), $\mathrm{BC}$ deposition (overestimation by 20 $100 \%$ ), and AAOT (difference of $<10 \%$ ). The difference in AAOT was less pronounced because the overestimation of the absorption enhancement was compensated by the overestimation of hygroscopic growth and the consequent loss due to incloud scavenging.

5 The modal approach was used in the current aerosol microphysics module, but the same conclusion can also be inferred for the sectional (or bin) approaches in terms of the advantage of the 5-category approach, namely, the soot and dust sections should be separated from the light-scattering hygroscopic particle section for detailed investigations of aerosolcloud-radiation interactions.

Comparisons with other widely used community models, such as CMAQ and WRF-Chem, should be made in the future. Multimodel inter-comparison is a useful way to improve the model performance and evaluate the model uncertainty. There is a 12-category method that was implemented to a regional model (Glassmeier et al., 2017). This is currently the ultimate representation of the category method. It is necessary to compare our 3- and 5-category methods to the 12-category approach as a benchmark simulation. There have been tremendous advancements in new particle formation, organic chemistry, and ice nucleation studies. This new knowledge should be timely and properly reflected in the modeling framework.

\section{Code availability}

The NHM-Chem source code is available subject to a license agreement with the Japan Meteorological Agency. Further information is available at http://www.mri-jma.go.jp/Dep/ap/nhmchem_model/application.html. Unfortunately this website is only in Japanese. Thus additionally, the source code, user's manual, analysis tools, and sets of boundary conditions can be provided upon request to the corresponding author.

\section{Acknowledgements}

This work was mainly supported by the Fundamental Research Budget of MRI (C3) and the Integrated Research Program for Advancing Climate Models (TOUGOU Program) of the Ministry of Education, Culture, Sports, Science, and Technology Japan (MEXT). This work was also supported by the Environmental Research and Technology Development Fund (5-1605, S-12, and 2-1703) of the Environmental Restoration and Conservation Agency (ERCA) and by the Japanese Society for the Promotion of Sciences (JSPS) KAKENHI Grant Number JP15H02811, JP16H04051, JP16H01772, JP15K16121, JP16KK0018, JP26701004, and JP18H03363) and in part by a grant for the Global Environmental Research Coordination System, from the Ministry of Environment, Japan (MOEJ). The authors feel obliged to thank Dr. Toshinori AOYAGI of the JMA, Prof. Mitsuo OHIZUMI of Meteorological College, and Drs. Hiroaki NAOE, Masashi NIWANO, and Masaya NOSAKA of the MRI for their useful comments on model developments. The authors feel obliged to thank the Kagoshima 
Geosci. Model Dev. Discuss., https://doi.org/10.5194/gmd-2018-128

Manuscript under review for journal Geosci. Model Dev.

Discussion started: 21 June 2018

(c) Author(s) 2018. CC BY 4.0 License.

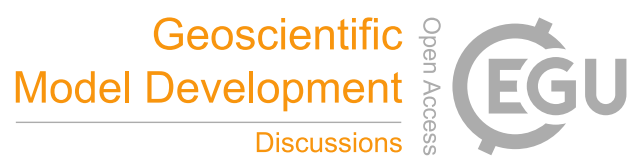

(c) (i)

Meteorological Office and Aso Volcano Disaster Prevention Council for providing the volcanic $\mathrm{SO}_{2}$ emission measurement data of Mt. Sakurajima and Mt. Aso, respectively. 
Geosci. Model Dev. Discuss., https://doi.org/10.5194/gmd-2018-128

Manuscript under review for journal Geosci. Model Dev.

Discussion started: 21 June 2018

(c) Author(s) 2018. CC BY 4.0 License.

\section{References}

Abdul-Razzak, H. and Ghan, S. J.: A parameterization of aerosol activation. 2. Multiple aerosol types. J. Geophys. Res., 105, 6837-6844, 2000.

Adachi, K., Chung, S. H. and Buseck, P. R.: Shapes of soot aerosol particles and implications for their effects on climate. J.

Geophys. Res., 115, D15206., 2010.

Andres R. J. and Kasgnoc, A. D.: A time-averaged inventory of subaerial volcanic sulfur emissions. J. Geophys. Res., 103(D19), 25,251-25,261, 1998

Andronache, C., Grönholm, T., Laakso, L., Phillips, V., and Venäläinen, A.: Scavenging of ultrafine particles by rainfall at a boreal site: observations and model estimations. Atmos. Chem. Phys., 6, 4739-4754, 2006.

10 Aoki, T., Tanaka, T. Y., Uchiyama, A., Chiba, M., Mikami, M., Yabuki, S., and Key, J. R.: Sensitivity experiments of direct radiative forcing caused by mineral dust simulated with a chemical transport model. J. Meteorol. Soc. Jpn., 83A, 315-331, 2005.

Bond, T. C., Habib, G., and Bergstrom, R. W.: Limitations in the enhancement of visible light absorption due to mixing state. J. Geophys. Res., 111, D20211, 13 pp, 2006.

Bond, T. C., Doherty, S. J., Fahey, D. W., Forster, P. M., Berntsen, T., DeAngelo, B. J., Flanner, M. G., Ghan, S., Kärcher, B., Koch, D., Kinne, S., Kondo, Y., Quinn, P. K., Sarofim, M. C., Schultz, M. G., Schlz, M., Venkataraman, C., Zhang, H., Zhang, S., Bellouin, N., Guttikunda, S. K., Hopke, P. K., Jacobson, M. Z., Kaiser, J. W., Klimont, Z., Lohmann, U., Schwarz, J. P., Shindell, D., Storelvmo, T., Warren, S. G., and Zender, C. S.: Bounding the role of black carbon in the climate system: A scientific assessment. J. Geophys. Res., 118, 1-173, 2013

Boucher, O., et al.: Clouds and aerosols. In: Stocker, T.F. (Ed.), Climate Change 2013: the Physical Science Basis, Working Group I Contribution to the Fifth Assessment Report of the Intergovernmental Panel on Climate Change. Cambridge Univ. Press, New York, pp. 571-657, 2013.

Burns, D. A., Lynch, J. A., Cosby, B. J., Fenn, M. E., Baron, J. S., US EPA Clean Air Markets Div.: National Acid Precipitation Assessment Program Report to Congress 2011: An integrated assessment, National Science and Technology Council, Washington, DC, 114 pp, 2011.

Byun, D., and Schere K.: Review of the governing equations, computational algorithms, and other components of the Models-3 Community Multiscale Air Quality (CMAQ) modeling system. Appl. Mech. Rev., 59, 51-77, 2006.

Carlton, A. G., Turpin, B. J., Altieri, K. E., Seitzinger, S., Reff, A., Lim, H.-J., and Ervens, B.: Atmospheric oxalic acid and SOA production from glyoxal: Results of aqueous photooxidation experiment. Atmos. Environ., 41, 7588-7602, 2007.

Carter, W.: Documentation of the SAPRC-99 chemical mechanism for VOC reactivity assessment. Final report to California Air Resources Board, Rep. 92-329, Univ. of Calif., Riverside, 8 May, 569 pp, 2000. 
Geosci. Model Dev. Discuss., https://doi.org/10.5194/gmd-2018-128

Manuscript under review for journal Geosci. Model Dev.

Discussion started: 21 June 2018

(c) Author(s) 2018. CC BY 4.0 License.

Chapman, E. G., Gustafson Jr. W. I., Easter, R. C., Barnard, J. C., Ghan, S. J., Pekour, M. S., and Fast, J. D.: Coupling aerosol-cloud-radiative processes in the WRF-Chem model: Investigating the radiative impact of elevated point sources. Atmos. Chem. Phys., 9, 945-964, 2009.

Chatani, S., Yamaji, K., Sakurai, T., Itahashi, S., Shimadera, H., Kitayama, K., and Hayami, H.: Overview of Model Inter5 Comparison in Japan's Study for Reference Air Quality Modeling (J-STREAM). Atmosphere, 9(1), 19, 14 pp, 2018.

Ching, J., Riemer, N., and West, M.: Impacts of black carbon mixing state on black carbon nucleation scavenging: Insights from a particle-resolved model. J. Geophys. Res., 117, D23209, 2012.

Ching, J., Zaveri, R.A., Easter, R. C., Riemer, N., and Fast, J. D.: A three-dimensional sectional representation of aerosol mixing state for simulating optical properties and cloud condensation nuclei. J. Geophys. Res., 121, 5912-5929, $2016 \mathrm{a}$.

10 Ching, J., Riemer, N., West, M.: Impacts of black carbon particles mixing state on cloud microphysical properties: Sensitivity to environmental conditions. J. Geophys. Res., 121, 5990-6013, $2016 \mathrm{~b}$.

Ching, J., J. Fast, M. West, N. Riemer, 2017: Metrics to quantify the importance of mixing state for CCN activity. Atmos. Chem. Phys., 17, 7445-7458.

Ching, J., West, M., and Riemer, N.: Quantifying impacts of aerosol mixing state on nucleation-scavenging of black carbon aerosol particles. Atmosphere, 9, 17, 17 pp, 2018.

Clarke, A. D., Owens, S. R., and Zhou, J.: An ultrafine sea-salt flux from breaking waves: Implications for cloud condensation nuclei in the remote marine atmosphere. J. Geophys. Res., 111, D06202, 14 pp, 2016.

Cohen, A. J., et al.: Urban air pollution, in Comparative Quantification of Health Risks: Global and Regional Burden of Disease Attributable to Selected Major Risk Factors, 1st ed., edited by M. Ezzati et al., Vol. 2, pp. 1353-1453, World Health Organization, Geneva, 2014.

Curtis, J. H., Riemer, N., and West, M.: A single-column particle-resolved model for simulating the vertical distribution of aerosol mixing state: WRF-PartMC-MOSAIC-SCM v1.0. Geosci. Model. Dev., 10, 4057-4079, 2017.

Deushi, M. and Shibata, K.: Development of an MRI Chemistry-Climate Model ver.2 for the study of tropospheric and stratospheric chemistry. Papers in Meteor. Geophys., 62, 1-46, 2011.

Edney, E. O., Kleindienst, T. E., Lewandowski, M., and Offenberg, J. H.: Updated SOA chemical mechanism for the Community Multiscale Air Quality model. EPA 600/X-07/025, US Environ. Prot. Agency, Durham, NC, 2007.

Emmons, L. K., Walters, S., Hess, P. G., Lamarque, J.-F., Pfister, G. G., Fillmore, D., Granier, C., Guenther, A., Kinnison, D., Laepple, T., Orlando, J., Tie, X., Tyndall, G, Wiedinmyer, C., Baughcum, S. L., and Kloste. S.: Description and evaluation of the Model for Ozone and Related chemical Tracers, version 4 (MOZART-4). Geosci. Model Dev., 3, 43-67, 2010.

Facchini, M. C., Rinaldi, M., Decesari, S., Carbone, C., Finessi, E., Mircea, M., Fuzzi, S., Ceburnis, D., Flanagan, R., Nilsson, E. D., de Leeuw, G., Martino, M., Woeltjen, J., and O’Dowd, C. D.: Primary submicron marine aerosol dominated by insoluble organic colloids and aggregates. Geophys. Res. Lett. 35, L17814, 5 pp, 2008. 
Geosci. Model Dev. Discuss., https://doi.org/10.5194/gmd-2018-128

Manuscript under review for journal Geosci. Model Dev.

Discussion started: 21 June 2018

(c) Author(s) 2018. CC BY 4.0 License.

Fountoukis, C. and Nenes, A.: ISORROPIA II: a computationally efficient thermodynamic equilibrium model for $\mathrm{K}^{+}-\mathrm{Ca}^{2+}-$ $\mathrm{Mg}^{2+}-\mathrm{NH}^{4+}-\mathrm{Na}^{+}-\mathrm{SO}_{4}{ }^{2-}-\mathrm{NO}_{3}{ }^{-}-\mathrm{Cl}^{-}-\mathrm{H}_{2} \mathrm{O}$ aerosols. Atmos. Chem. Phys., 7, 4639-4659, 2007.

Fukui, T., Kokuryo, K., Baba, T., and Kannari, A.: Updating EAGrid2000-Japan emissions inventory based on the recent emission trends. J. Jpn. Soc. Atmos. Environ., 49(2), 117-125, 2014 (in Japanese).

5 Giglio, L., Randerson, J. T., van der Werf, G. R., Kasibhatla, P. S., Collatz, G. J., Morton, D. C., and DeFries, R. S.: Assessing variability and long-term trends in burned area by merging multiple satellite fire products. Biogeosciences, 7 , 1171-1186, 2010.

Glassmeier, F., Possner, A., Vogel, B., Vogel, H., and Lohmann, U.: A comparison of two chemistry and aerosol schemes on the regional scale and the resulting impact on radiative properties and liquid- and ice-phase aerosol-cloud interactions, Atmos. Chem. Phys., 17, 8651-8680, 2017.

Grell, G. A., Peckham, S. E., Schmitz, R., McKeen, S. A., Frost, G., Skamarock, W. C., and Eder, B.: Fully coupled "online" chemistry within the WRF model. Atmos. Environ., 39, 6957-6975, 2005.

Guenther, A., Karl, T., Harley, P., Wiedinmyer, C., Palmer, P. I., and Geron, C.: Estimates of global terrestrial isoprene emissions using MEGAN (Model of Emissions of Gases and Aerosols from Nature). Atmos. Chem. Phys., 6, 3181-3210, 2006.

Han, Z., Ueda, H., Matsuda, K., Zhang, R.., Arao, K., Kanai, Y., and Hasome, H.: Model study on particle size segregation and deposition during Asian dust events in March 2002. J. Geophys. Res., 109, D19205, 22 pp, 2004.

Hess, M., Koepke, P., and Schult, I.: Optical properties of aerosols and clouds: the software package OPAC. B. Am. Meteorol. Soc., 79(5), 831-844, 1998.

20 Ishikawa, H.: Mass-consistent wind model as a meteorological preprocessor for tracer transport models. J. Appl. Meteorol., 33, 733-743, 1994.

Jacob, D. J.: Heterogeneous chemistry and tropospheric ozone. Atmos. Environ., 34, 2131-2159, 2000.

Jacobson, M. Z.: Analysis of aerosol interactions with numerical techniques for solving coagulation, nucleation, condensation, dissolution, and reversible chemistry among multiple size distributions. J. Geophys. Res., 107, D19, 4366, 2002.

JMA: The next generation non-hydrostatic model asuca. Suuchi Yohoka Hokoku Bessatsu (Additonal Volume to Report of Numerical Prediction Division) 60, 151 pp., 2014 (in Japanese)

Kajino, M., Ueda, H., Satsumabayashi, H., and An, J.: Impacts of the eruption of Miyakejima Volcano on air quality over far east Asia. J. Geophys. Res., 109, D21204, 11 pp, 2004.

Kajino, M.: MADMS: Modal Aerosol Dynamics model for multiple Modes and fractal Shapes in the free-molecular and near-continuum regimes. J. Aerosol Sci., 42, 224-248, 2011.

Kajino, M. and Kondo, Y.: EMTACS: Development and regional-scale simulation of a size, chemical, mixing type, and soot shape resolved atmospheric particle model. J. Geophys. Res., 116, D02303, 28 pp, 2011. 
Geosci. Model Dev. Discuss., https://doi.org/10.5194/gmd-2018-128

Manuscript under review for journal Geosci. Model Dev.

Discussion started: 21 June 2018

(c) Author(s) 2018. CC BY 4.0 License.

Kajino, M., Inomata, Y., Sato, K., Ueda, H., Han, Z., An, J., Katata, G., Deushi, M., Maki, T., Oshima, N., Kurokawa, J., Ohara, T., Takami, A., and Hatakeyama, S.: Development of the RAQM2 aerosol chemical transport model and predictions of the Northeast Asian aerosol mass, size, chemistry, and mixing type. Atmos. Chem. Phys., 12, 11833-11856, 2012a.

5 Kajino, M., Deushi, M., Maki, T., Oshima, N., Inomata, Y., Sato, K., Ohizumi, T., and Ueda, H.: Modeling wet deposition and concentration of inorganics over Northeast Asia with MRI-PM/c. Geosci. Model Dev., 5, 1363-1375, $2012 \mathrm{~b}$.

Kajino, M., Sato, K., Inomata, Y., and Ueda, H.: Source-receptor relationships of nitrate in Northeast Asia and influence of sea salt on the long-range transport of nitrate. Atmos. Environ., 79, 67-78, 2013.

Kajino, M., Ueda, H., Han, Z., Kudo, R., Inomata, Y., and Kaku, H.: Synergy between air pollution and urban meteorological changes through aerosol-radiation-diffusion feedback - A case study of Beijing in January 2013. Atmos. Environ., 171, 98-110, 2017.

Kajino, M., Deushi, M., Oshima, N., Sekiyama, T. T., Yumimoto, K., Tanaka, T. Y., Ching, J., Hashimoto, A., Yamamoto, T., Ikegami, M., Kamada, A., Miyashita, M., Inomata, Y., Shima, S., Takami, A., Shimizu, A., Hatakeyama, S., Sadanaga, Y., Irie, H., Adachi, K., Zaizen, Y., Igarashi, Y., Ueda, H., Maki, T., and Mikami, M., NHM-Chem, the Japan Meteorological Agency's regional meteorology - chemistry model: toward the consistent predictions of the chemical, physical, and optical properties of aerosols and their regional budget. J. Meteor. Soc. Japan, 2018a, in review.

Kajino, M., Sekiyama, T. T., Igarashi, Y., Katata, G., Sawada, M., Adachi, K., Zaizen, Y., Tsuruta, H., Nakajima, T.: Deposition and dispersion of radio-cesium released due to the Fukushima nuclear accident: Sensitivity to meteorological models and physical modules, J. Geophys. Res., 2018b, in review.

Kameda, T., Azumi, E., Fukushima, A., Tang, N., Matsuki, A., Kamiya, Y., Toriba, A., and Hayakawa, K.: Mineral dust aerosols promote the formation of toxic nitropolycyclic aromatic compounds. Sci. Rep., 6, 24427, 10 pp, 2016.

Kannari, A., Tonooka, Y., Baba, T., and Murano, K.: Development of multiple-species $1 \mathrm{~km} \times 1 \mathrm{~km}$ resolution hourly basis emissions inventory for Japan. Atmos. Environ., 41, 3428-3439, 2007.

Katata, G., Nagai, H., Wrzesinsky, T., Klemm, O., Eugster, W., and Burkard, R.: Development of a land surface model including cloud water deposition on vegetation. J. Appl. Meteo. Clim., 47, 2129-2146, 2008.

Katata, G., Nagai, H., Zhang, L., Held, A., Serça, D., and Klemm, O.: Development of an atmosphere-soil-vegetation model for investigation of radioactive materials transport in the terrestrial biosphere. P. Nucl. Sci. Technol., 2, 530-537, 2011.

Katata, G., Chino, M., Kobayashi, T., Terada, H., Ota, M., Nagai, H., Kajino, M., Draxler, R., Hort, M. C., Malo, A., Torii, T., and Sanada. Y.: Detailed source term estimation of the atmospheric release for the Fukushima Daiichi Nuclear Power Station accident by coupling simulations of an atmospheric dispersion model with an improved deposition scheme and oceanic dispersion model. Atmos. Chem. Phys., 15, 1029-1070, 2015.

Kobayashi, S., Ota, Y., Harada, Y., Ebita, A., Moriya, M., Onda, H., Onogi, K., Kamahori, H., Kobayashi, C., Endo, H., Miyaoka, K., and Takahashi, K.: The JRA-55 Reanalysis: General specifications and basic characteristics. J. Meteor. Soc. Japan, 93, 5-48, 2015. 
Geosci. Model Dev. Discuss., https://doi.org/10.5194/gmd-2018-128

Manuscript under review for journal Geosci. Model Dev.

Discussion started: 21 June 2018

(c) Author(s) 2018. CC BY 4.0 License.

Koike, M., Takegawa, N., Moteki, N., Kondo, Y., Nakamura, H., Kita, K., Matsui, H., Oshima, N., Kajino, M., and Nakajima, T. Y.: Measurements of regional-scale aerosol impacts on cloud microphysics over the East China Sea: Possible influences of warm sea surface temperature over the Kuroshio ocean current. J. Geophys. Res., 117, D17205, 21 pp, 2012.

5 Kondo, Y., Oshima, N., Kajino, M., Mikami, R., Moteki, N., Takegawa, N., Verma, R. L., Kajii, Y., Kato, S., and Takami, A.: Emissions of black carbon in East Asia estimated from observations at a remote site in the East China Sea. J. Geophys. Res., 116, D16201, 14 pp, 2011.

Kuang, C., McMurry, P. H., McCormick, A. V., and Eisele, F. L.: Dependence of nucleation rates on sulfuric acid vapor concentration in diverse atmospheric locations. J. Geophys. Res., 113, D10209, 9 pp, 2008.

10 Kunii, M.: Mesoscale data assimilation for a local severe rainfall event with the NHM-LETKF system. Wea. Forecasting, 29, 1093-1105, 2014.

Kurokawa, J., Ohara, T., Uno, I., Hayasaki, M., and Tanimoto, H.: Influence of meteorological variability on interannual variations of springtime boundary layer ozone over Japan during 1981-2005. Atmos. Chem. Phys., 9, 6287-6304, 2009.

Li, M., Zhang, Q., Kurokawa, J.-I., Woo, J.-H., He, K., Lu, Z., Ohara, T., Song, Y., Streets, D. G., Carmichael, G. R., Cheng, Y., Hong, C., Huo, H., Jiang, X., Kang, S., Liu, F., Su, H., and Zheng, B.: MIX: a mosaic Asian anthropogenic emission inventory under the international collaboration framework of the MICS-Asia and HTAP, Atmos. Chem. Phys., 17, 935963, 2017.

Lin, Y.-L., Farley, R. D., and Orville, H. D.: Bulk parameterization of the snow field in a cloud model. J. Appl. Meteo. Clim., 22, 1065-1092, 1983.

20 Liu, X., Easter, R. C., Ghan, S. J., Zaveri, R., Rasch, P., Shi, X., Lamarque, J.-F., Gettelman, A., Morrison, H., Vitt, F., Conley, A., Park, S., Naele, R., Hannay, C., Ekman, A. M. L., Hess, P., Mahowald, N., Collins, W., Iacono, M. J., Bretherton, C. S., Flanner, M. G., and Mitchell, D.: Toward a minimal representation of aerosols in climate models: description and evaluation in the Community Atmosphere Model CAM5. Geosci. Model Dev., 5, 709-739, 2012.

Liu, X., Ma, P.-L., Wang, H., Tilmes, S., Singh, B., Easter, R. C., Ghan, S. J., and Rasch, P. J.: Description and evaluation of a new four-mode version of the Modal Aerosol Module (MAM4) within version 5.3 of the Community Atmosphere Model. Geosci. Model Dev., 9, 502-522, 2016.

Lohmann, U. and Diehl, K.: Sensitivity studies of the importance of dust ice nuclei for the indirect aerosol effect on stratiform mixedphase clouds. J. Atmos. Sci., 63, 968-982, 2006.

Madronich, S.: Photodissociation in the atmosphere: 1. Actinic flux and the effects of ground reflections and clouds. J. Geophys. Res., 92, 9740-9752, 1987.

Matsui, H.: Development of a global aerosol model using a two-dimensional sectional method: 1. Model design. J. Adv. Model. Earth Syst., 9, 1921-1947, 2017. 
Geosci. Model Dev. Discuss., https://doi.org/10.5194/gmd-2018-128

Manuscript under review for journal Geosci. Model Dev.

Discussion started: 21 June 2018

(c) Author(s) 2018. CC BY 4.0 License.

Miyakawa, T., Takeda, N., Koizumi, K., Tabaru, M., Ozawa, Y., Hirayama, N., and Takegawa, N.: A new lase induced incandescence - mass spectrometric analyzer (LII-MS) for online measurement of aerosol composition classified by black carbon mixing state. Aerosol Sci. Tech., 48, 853-863, 2014.

Murakami, M., Magono, C., and Kikuchi, K.: Experiments on aerosol scavenging by natural snow crystals, Part III: The effect of snow crystal charge on collection efficiency. J. Meteorol. Soc. Jpn., 63, 1127-1137, 1985.

Nakano, M., Kato, T., Hayashi, S., Kanada, S., Yamada, Y., and Kurihara, K.: Development of a 5-km-Mesh Cloud-SystemResolving Regional Climate Model at the Meteorological Research Institute. J. Meteorol. Soc. Jpn., 90A, 339-350, 2012.

Pleim, J. E. and Chang, J. S.: A non-local closure model for vertical mixing in the convective boundary layer. Atmos. Environ., 26A, 965-981, 1992.

Oshima, N., Koike, M., Zhang, Y., Kondo, Y., Moteki, N., Takegawa, N., and Miyazaki, Y.: Aging of black carbon in outflow from anthropogenic sources using a mixing state resolved model: Model development and evaluation. J. Geophys. Res., 114, D06210, 2009a.

Oshima, N., Koike, M., Zhang, Y., and Kondo, Y.: Aging of black carbon in outflow from anthropogenic sources using a mixing state resolved model: 2. Aerosol optical properties and cloud condensation nuclei activities, J. Geophys. Res., 114, D18202, 17 pp, 2009b.

Petters, M. D. and Kreidenweis, S. M.: A single parameter representation of hygroscopic growth and cloud condensation nucleus activity. Atmos. Chem. Phys., 7, 1961-1971, 2007.

Prather, K. A., Bertram, T. H., Grassian, V. H., Deane, G. B., Stokes, M. D., Demott, P. J., Aluwihare, L. I., Palenik, B. P., Azam, F., Seinfeld, J. H., Moffet, R. C., Molina, M. J., Cappa, C. D., Geiger, F. M., Roberts, G. C., Russel, L. M., Ault, A. P., Baltrusaitis, J., Collins, D. B., Corrigan, C. E., Cuadra-Rodriguez, L. A., Ebben, C. J., Forestieri, S. D., Guasco, T. L., Hersey, S. P., Kim, M. J., Lambert, W. F., Modini, R. L., Mui, W., Pedler, B. E., Ruppel, M. J., Ryder, O. S., Schoepp, N. G., Sullivan, R. C., and Zhao, D.: Bringing the ocean into the laboratory to probe the chemical complexity of sea spray aerosol. Proc. Natl. Acad. Sci., 110(19), 7550-7555, 2013.

Rasmussen, R. M., Geresdi, I., Thompson, G., Manning, K., and Karplus, E.: Freezing drizzle formation in stably stratified layer clouds: The role of radiation cooling of cloud droplets, cloud condensation nuclei, and ice initiation. J. Atmos. Sci., 59, 837-860, 2002.

Saito, K., Fujita, T., Yamada, Y., Ishida, J., Kumagai, Y., Aranami, K., Ohmori, S., Nagasawa, R., Kumagai, S., Muroi, C., Kato, T., Eito, H., and Yamazaki, Y.: The operational JMA nonhydrostatic mesoscale model. Mon. Wea. Rev., 134, 1266-1298, 2006. operational development at JMA. J. Meteor. Soc. Japan, 85B, 271-304, 2007.

Seinfeld, J. H. and Pandis, S. N.: Atmospheric Chemistry and Physics: From Air Pollution to Climate Change, 2nd Edition, 1203 pp., John Wiley, New York, 2006. 
Geosci. Model Dev. Discuss., https://doi.org/10.5194/gmd-2018-128

Manuscript under review for journal Geosci. Model Dev.

Discussion started: 21 June 2018

(c) Author(s) 2018. CC BY 4.0 License.

Sekiyama, T. T., Kunii, M., Kajino, M., and Shimbori, T.: Horizontal resolution dependence of atmospheric simulations of the Fukushima nuclear accident using 15-km, 3-km, and 500-m Grid Models. J. Meteor. Soc. Japan, 93, 49-64, 2015.

Skamarock, W. C., Klemp, J. B., Dudhia, J., Gill, D. O., Barker, D. M., Duda, M. G., Huang, X. Y., Wang, W., and Powers, J. G.: A description of the advanced research WRF version 3. Tech. Note, NCAR/TN 475+STR, 125 pp., Natl. Cent. for Atmos. Res., Boulder, Colo, 2008.

Slinn, W. G. N.: Precipitation scavenging, in: Atmospheric Science and Power Production. Chap. 11, edited by: Randerson, D., No. DOE/TIC-27601, US Department of Energy, Washington, DC, 466-532, 1984.

Song, C. H. and Carmichael, G. R.: A three-dimensional modeling investigation of the evolution processes of dust and seasalt particles in east Asia. J. Geophys. Res., 106(D16), 18,131-18,154, 2001.

10 Sudo, K., Takahashi, M., Kurokawa, J., and Akimoto, H.: CHASER: A global chemical model of the troposphere 1. Model description. J. Geophys. Res., 107, D17, 4339, 2002.

Takemura, T., Nozawa, T., Emori, S., Nakajima, T. Y., and Nakajima, T.: Simulation of climate response to aerosol direct and indirect effects with aerosol transport-radiation model, J. Geophys. Res., 110, D02202, 2005.

Tanaka, T. Y., Orito, K., Sekiyama, T. T., Shibata, K., Chiba, M., and Tanaka, H.: MASINGAR, a global tropospheric aerosol chemical transport model coupled with MRI/JMA98 GCM: Model description. Pap. Meteor. Geophys., 53(4), 119-138, 2003.

Tanaka, T. Y. and Ogi, A.: Update of Japan Meteorological Agency's global mineral dust operational forecast model. Sokkou-Jihou, 84, 109-128, 2017 (in Japanese).

Tanaka, T. Y., Ogi, A., Yumimoto, K. et al.: Performance of the aerosol forecasting system using the global aerosol model MASINGAR and the data assimilation with satellite observations, to be submitted to Atmosphere, 2018.

Uno, I., Nagata, K., Yumimoto, K., Itahashi, S., Kuwata, S., Pan, X., Hara, Y., and Yamamoto, S.: Numerical analysis of trans-boundary transport of dust-nitrate during the long-lasting yellow sand episode observed over the Northern Kyushu Area in late May-early June 2014, J. Jpn. Soc. Atmos. Environ., 51, 181-189, 2016 (in Japanese).

Uno, I., Osada, K., Yumimoto, K., Wang, Z., Itahashi, S., Pan, X., Hara, Y., Kanaya, Y., Yamamoto, S., and Fairlie, T. D.: Seasonal variation of fine- and coarse-mode nitrates and related aerosols over East Asia: synergetic observations and chemical transport model analysis. Atmos. Chem. Phys., 17(23), 14,181-14,197, 2017.

Vogel, B., Vogel, H., Bäumer, D., Bangert, M., Lundgren, K., Rinke, R., and Stanelle, T.: The comprehensive model system COSMO-ART - Radiative impact of aerosol on the state of the atmosphere on the regional scale, Atmos. Chem. Phys., 9, 8661-8680, 2009.

Walcek, C. J. and Aleksic, N. M.: A simple but accurate mass conservative peak-preserving, mixing ratio bounded advection algorithm with fortran code. Atmos. Environ., 32, 3863-3880, 1998.

Walcek, C. J. and Taylor, G. R.: A theoretical method for computing vertical distributions of acidity and sulfate production within cumulus clouds. J. Atmos. Sci., 43, 339-355, 1986. 
Geosci. Model Dev. Discuss., https://doi.org/10.5194/gmd-2018-128

Manuscript under review for journal Geosci. Model Dev.

Discussion started: 21 June 2018

(c) Author(s) 2018. CC BY 4.0 License.

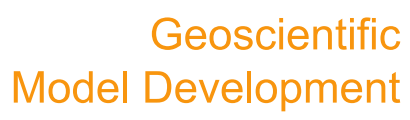

Discussions

(c) $\underset{\text { BY }}{\text { (i) }}$

Wang, X., Zhang, L., and Moran, M. D.: Uncertainty assessment of current size-resolved parameterizations for below-cloud particle scavenging by rain. Atmos. Chem. Phys., 10, 5685-5705, 2010.

WHO: IARC monographs on the evaluation of carcinogenic risks to humans, Ionizing radiation, part 2: Some internally deposited radionuclides, Vol. 78, $595 \mathrm{pp}, 2001$.

5 Wong, D. C, Pleim, J., Mathur, R., Binkowski, F., Otte, T., Gilliam, R., Pouliot, G., Xiu, A., Young, J. O., and Kang, D.: WRF-CMAQ two-way coupled system with aerosol feedback: software development and preliminary results. Geosci. Model Dev., 5, 299-312, 2012.

Woo, J.-H., Streets, D. G., Carmichael, G. R., Tang, Y., Yoo, B., Lee, W.-C., Thongboonchoo, N., Pinnock, S., Kurata, G., Uno, I., Fu, Q., Vay, S., Sachse, G. W., Clake, D. R., Fried, A., and Thornton, D. C.: Contribution of biomass and biofuel emissions to trace gas distributions in Asia during the TRACE-P experiment. J. Geophys. Res., 108(D21), 8812, 2003.

Zaveri, R. A., Barnard, J. C., Easter, R. C., Riemer, N., and West, M.: Particle-resolved simulation of aerosol size, composition, mixing state, and the associated optical and cloud condensation nuclei activation properties in an evolving urban plume. J. Geophys. Res., 115, D17210, 2010.

Zhang, D., and Iwasaka, Y.: Size change of Asian dust particles caused by sea salt interaction: Measurements in southwestern Japan. Geophys. Res. Lett., 31, L15102, 4 pp, 2004.

Zhang, K., O’Donnell, D., Kazil, J., Stier, P., Kinne, S., Lohmann, U., Ferrachat, S., Croft, B., Quaas, J., Wan, H., Rast, S., and Feichter, J.: The global aerosol-climate model ECHAM-HAM, version 2: sensitivity to improvements in process representations, Atmos. Chem Phys. 12, 8911-8949, 2012.

Zhang, L., Gong, S., Padro, J., and Barrie, L.: A size-segregated particle dry deposition scheme for an atmospheric aerosol module. Atmos. Environ., 35, 549-560, 2001.

Zhang, L., Brook, J. R., and Vet, R.: A revised parameterization for gaseous dry deposition in air-quality models. Atmos. Chem. Phys., 3, 2067-2082, 2003.

Zhang, L., Wang, X., Moran, M. D., and Feng, J.: Review and uncertainty assessment of size-resolved scavenging coefficient formulations for below-cloud snow scavenging of atmospheric aerosols. Atmos. Chem. Phys., 13, 10005$10025,2013$. 
Geosci. Model Dev. Discuss., https://doi.org/10.5194/gmd-2018-128

Manuscript under review for journal Geosci. Model Dev.

Discussion started: 21 June 2018

(c) Author(s) 2018. CC BY 4.0 License.

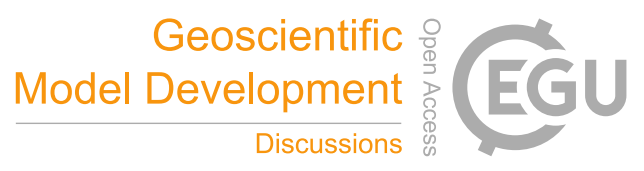

(c) (i)

(a) 5-category non-equilibrium method

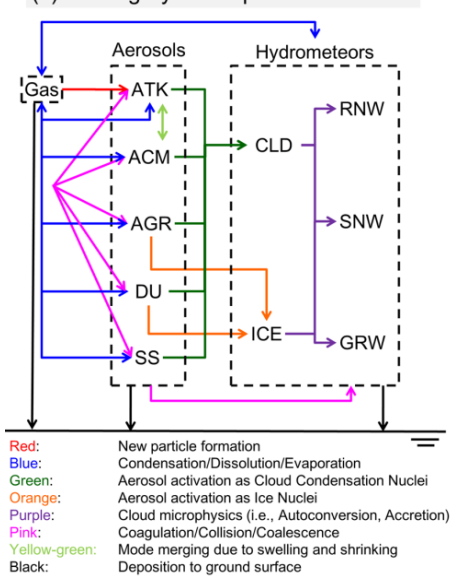

(b) 3-category non-equilibrium method

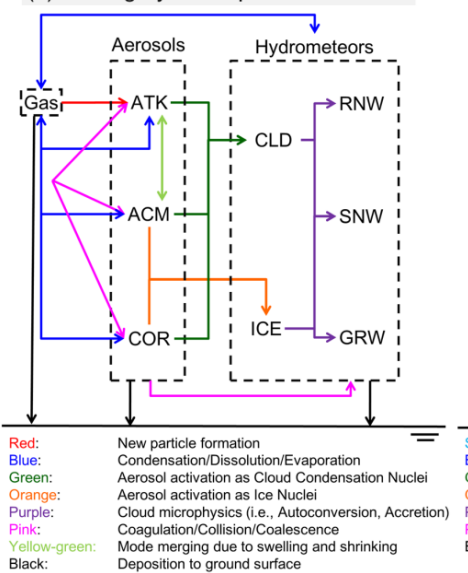

(c) Bulk equilibrium method

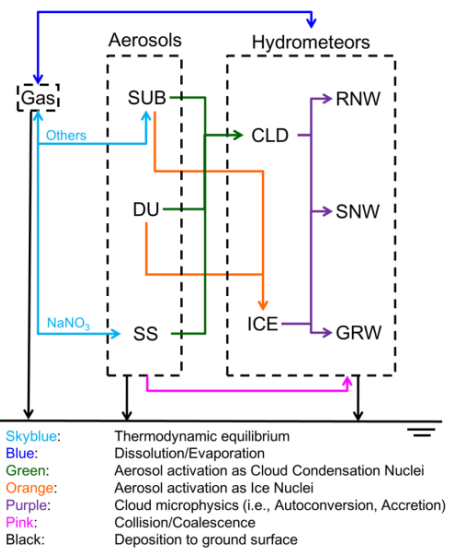

Figure 1: Schematic illustrations of gas-aerosol-cloud dynamic processes considered in (a) 5-category (unique

feature), (b) 3-category (global standard), and (c) bulk equilibrium (unique feature) categories. ATK (Aitken mode), ACM (soot-free accumulation mode, 5-category; accumulation mode, 3-category), AGR (accumulation mode, mixed with soot aggregate) DU (mixture with dust; both mineral and anthropogenic dust), SS (mixture with sea-salt), COR (coarse mode), SUB (submicron), CLD (cloud), ICE (cloud ice), RNW (rain), SNW (snow), GRW (graupel). 
Geosci. Model Dev. Discuss., https://doi.org/10.5194/gmd-2018-128 Manuscript under review for journal Geosci. Model Dev.

Discussion started: 21 June 2018

(c) Author(s) 2018. CC BY 4.0 License.

(c) (i)
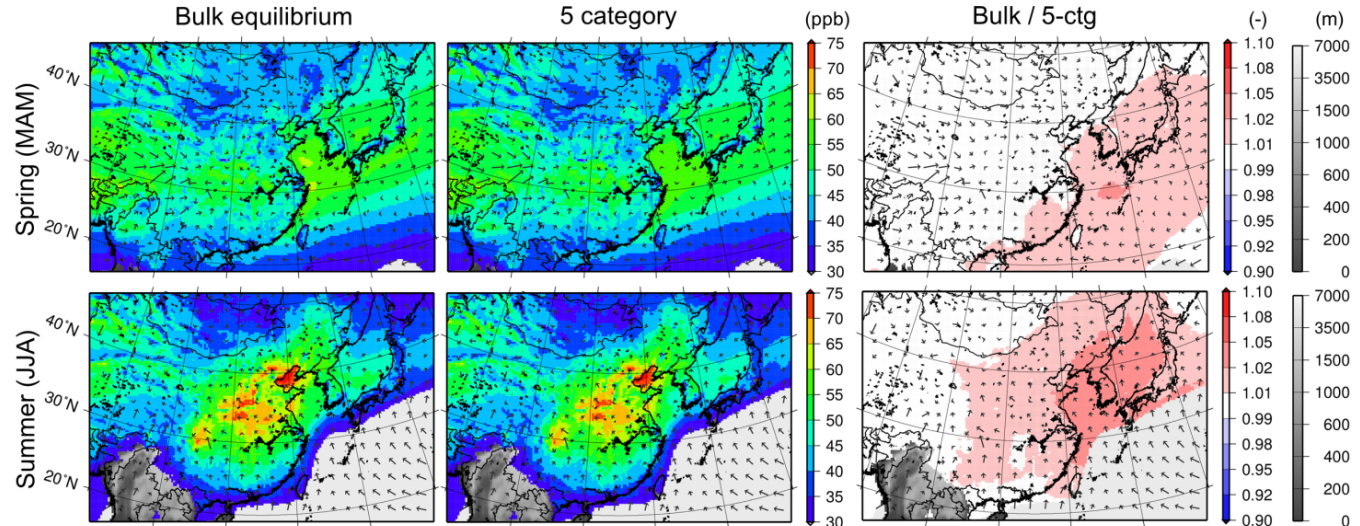

$\left.\begin{array}{r}1.10 \\ 1.08 \\ -1.05 \\ -1.02 \\ -1.01 \\ 0.99 \\ 0.98 \\ 0.95 \\ 0.92 \\ 0.90\end{array}\right]-\begin{array}{r}7000 \\ 3500 \\ 1500 \\ 1000 \\ 600 \\ 400 \\ 200 \\ 0\end{array}$
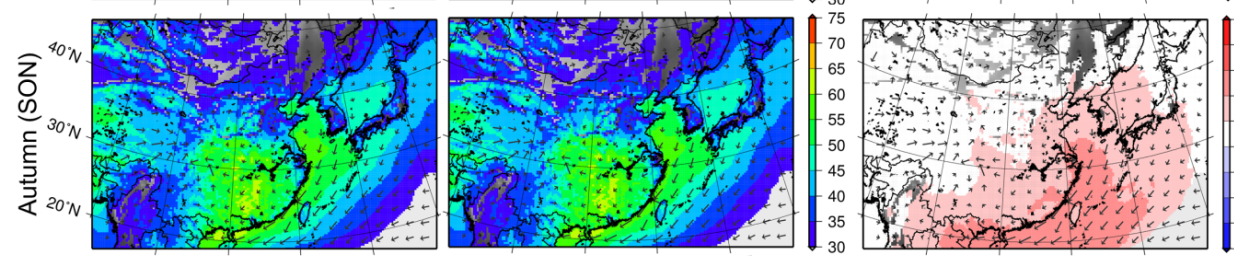

$\begin{array}{r}-1.10 \\ -1.08 \\ -1.05 \\ -1.02 \\ -1.01 \\ -0.99 \\ -0.98 \\ 0.95 \\ -0.92 \\ 0.90\end{array} \square-\begin{array}{r}7000 \\ -3500 \\ 1500 \\ -1000 \\ 600 \\ 400 \\ 200 \\ 0\end{array}$
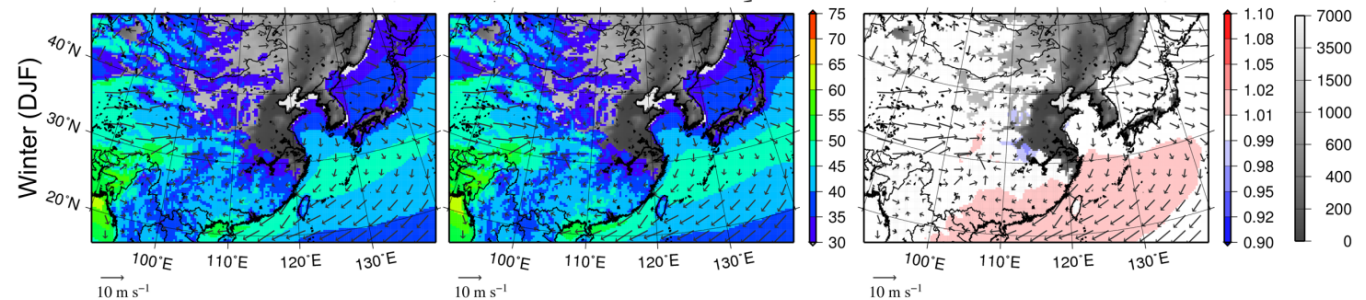

Figure 2: Seasonal mean surface air concentrations of $\mathrm{O}_{3}$ in (top to bottom) Spring, Summer, Autumn, and Winter of the year 2006 for (left to right) the bulk method, the 5-category method, and the ratios of the bulk to 5-category methods with surface wind vectors. Model topography is depicted in grayscale on the background of each panel. Topography is overwrapped by color shades for concentrations above the lower limit of the scale (in this case, 30 ppb). 
Geosci. Model Dev. Discuss., https://doi.org/10.5194/gmd-2018-128 Manuscript under review for journal Geosci. Model Dev.

Discussion started: 21 June 2018

(c) Author(s) 2018. CC BY 4.0 License.

\section{Geoscientific Model Development \\ Discussions} (c) (1)
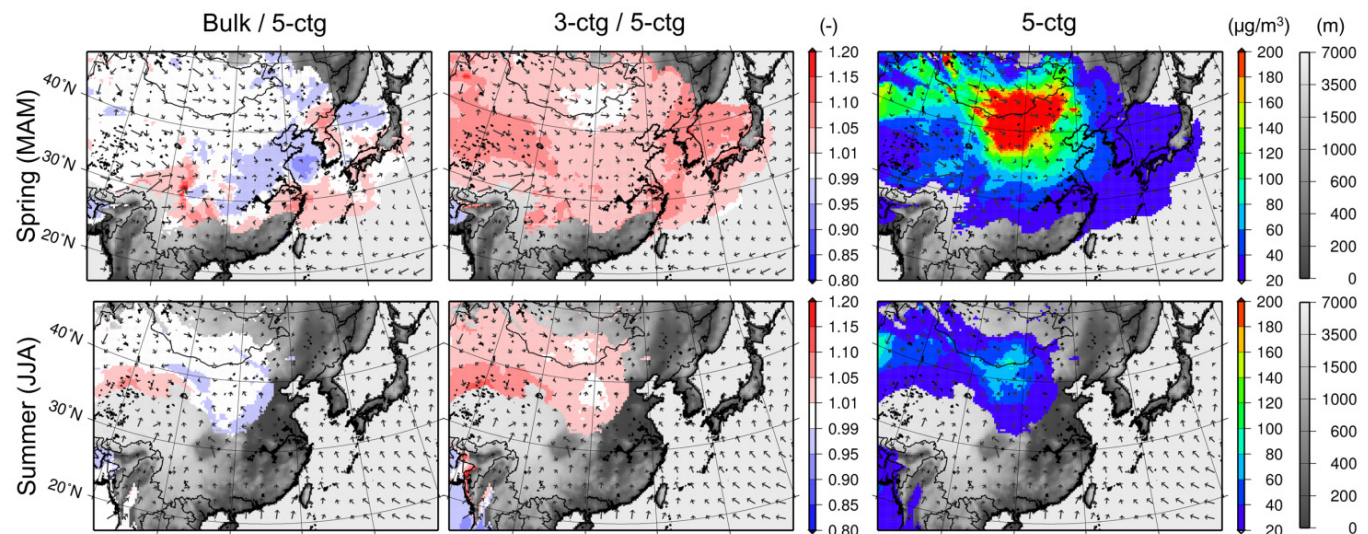

$\left[\begin{array}{r}200 \\ 180 \\ 160 \\ 140 \\ 120 \\ 100 \\ 80 \\ 60 \\ 40 \\ 20\end{array}\right]-\left[\begin{array}{r}7000 \\ 3500 \\ 1500 \\ 1000 \\ 600 \\ 400 \\ 200 \\ 0\end{array}\right.$
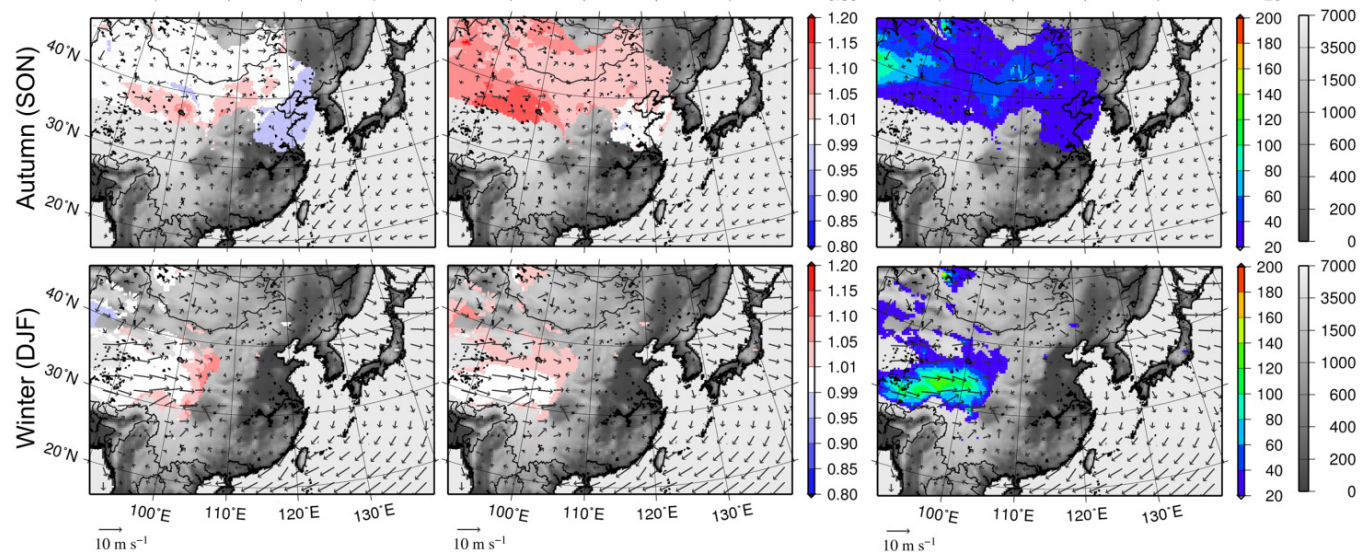

Figure 3: Same as Fig. 2 but for mineral dust for (left to right) the ratios of the bulk to 5-category methods, the ratios of the 3-category to 5-category methods, and the 5-category method. 
Geosci. Model Dev. Discuss., https://doi.org/10.5194/gmd-2018-128

Manuscript under review for journal Geosci. Model Dev.

Discussion started: 21 June 2018

(c) Author(s) 2018. CC BY 4.0 License.

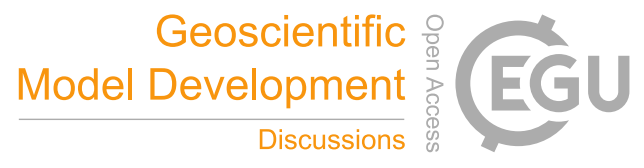

(c) $\underset{\mathrm{BY}}{\mathrm{B}}$
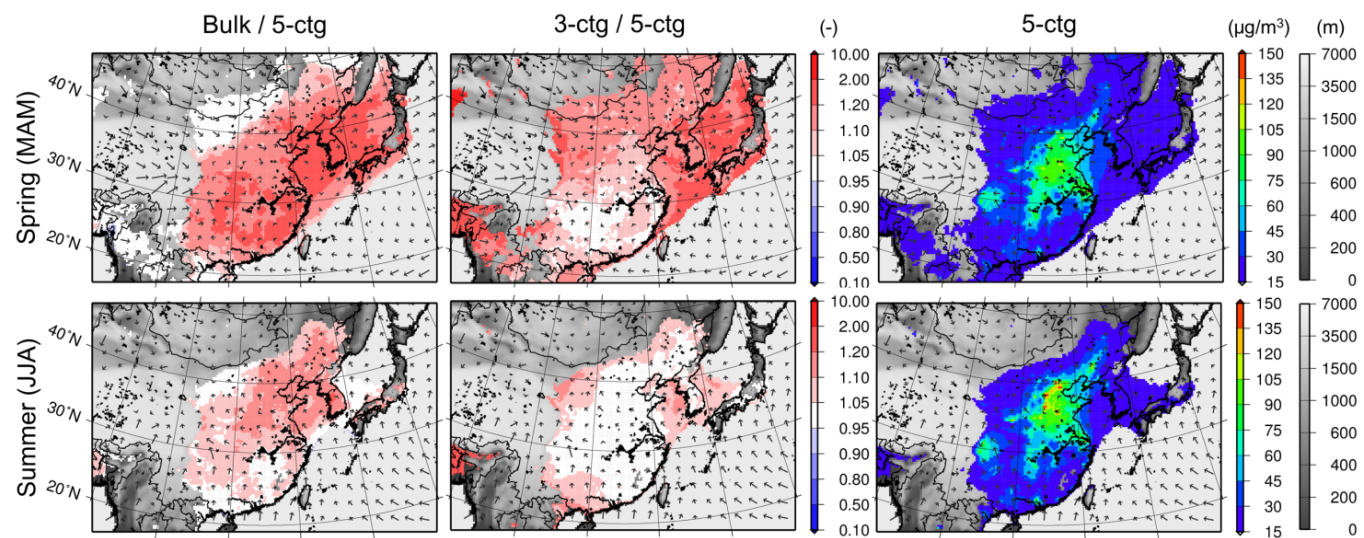

$\begin{array}{r}150 \\ 135 \\ 120 \\ 105 \\ 90 \\ 75 \\ 60 \\ 45 \\ 30 \\ 15\end{array} \llbracket-\begin{array}{r}7000 \\ 3500 \\ 1500 \\ -1000 \\ 600 \\ 400 \\ 200 \\ 0\end{array}$
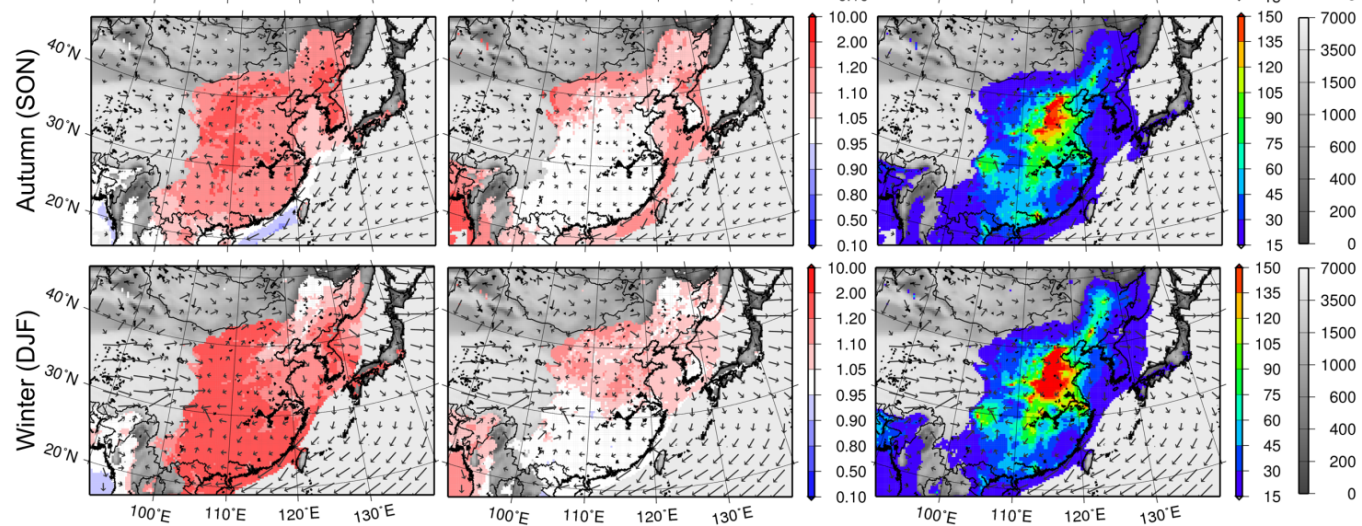

Figure 4: Same as Fig. 3 but for $\mathrm{PM}_{2.5}$. 
Geosci. Model Dev. Discuss., https://doi.org/10.5194/gmd-2018-128 Manuscript under review for journal Geosci. Model Dev.

Discussion started: 21 June 2018

(c) Author(s) 2018. CC BY 4.0 License.

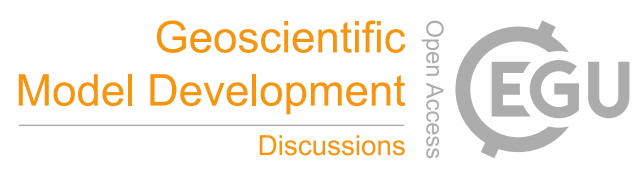

(c) $\underset{\mathrm{BY}}{\mathrm{B}}$
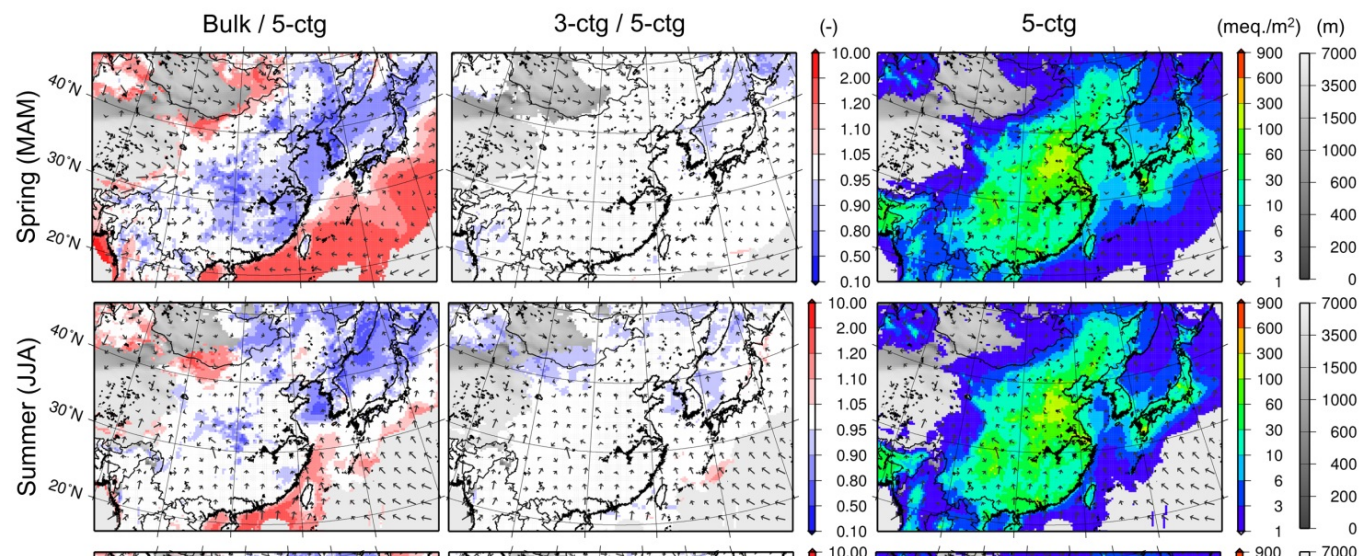

$\int_{-600}^{900} \pi-3000$
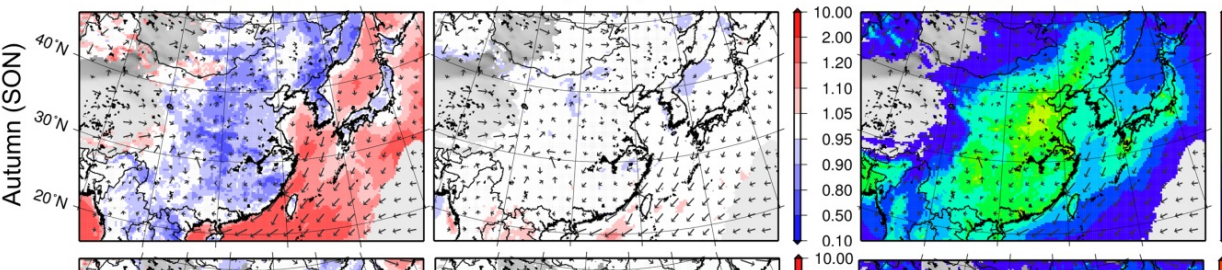

$\left.\begin{array}{l||l}-300 \\ -100\end{array}\right]-1500$
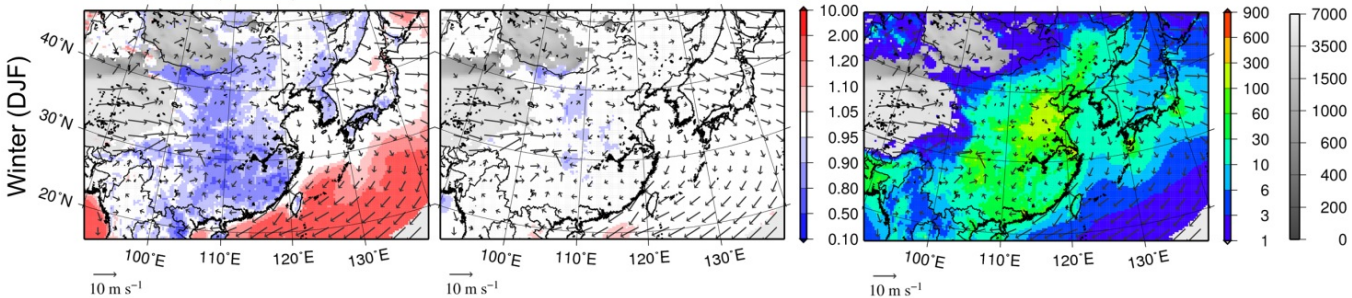

Figure 5: Same as Figs. 3 and 4 but for the dry deposition of $\mathrm{SO}_{4}{ }^{2-}$ and $\mathrm{T}_{-} \mathrm{NH}_{4}{ }^{+}$plus $\mathrm{T}-\mathrm{NO}_{3}{ }^{-}$. 
Geosci. Model Dev. Discuss., https://doi.org/10.5194/gmd-2018-128 Manuscript under review for journal Geosci. Model Dev.

Discussion started: 21 June 2018

(c) Author(s) 2018. CC BY 4.0 License.

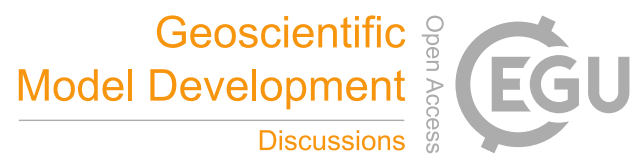

(c) $\underset{\mathrm{BY}}{\mathrm{B}}$
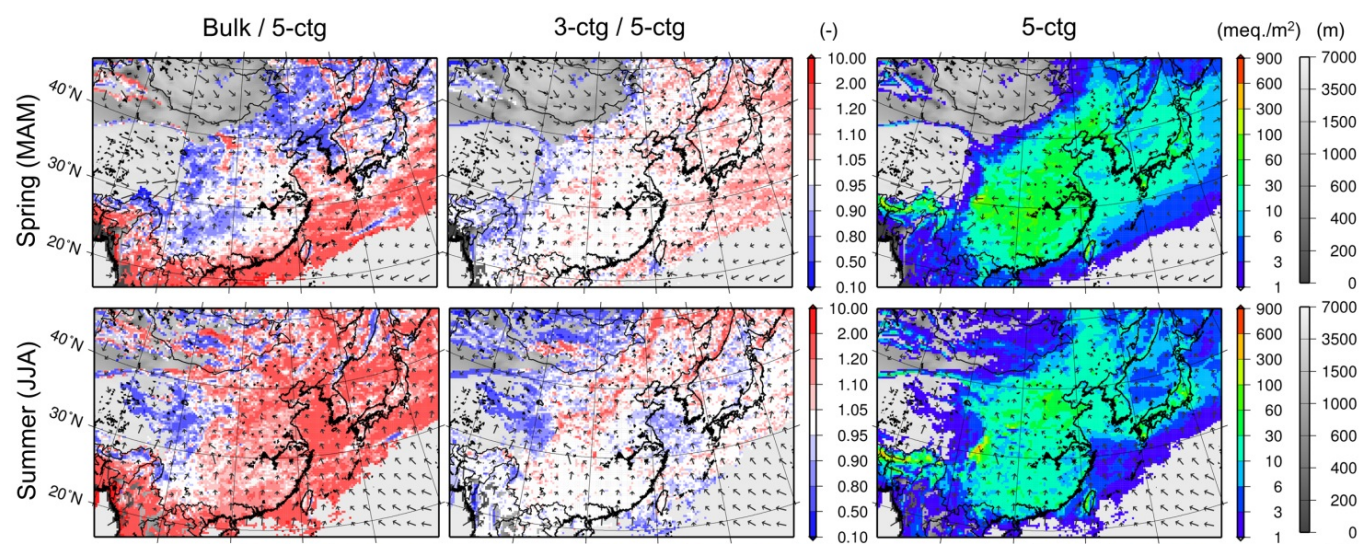

$\left[\begin{array}{r}900 \\ 600 \\ 300 \\ 100 \\ 60 \\ 30 \\ 10 \\ 6 \\ 3 \\ 1\end{array}\right]-\begin{array}{r}7000 \\ 3500 \\ 1500 \\ 1000 \\ 600 \\ 400 \\ 200 \\ 0\end{array}$
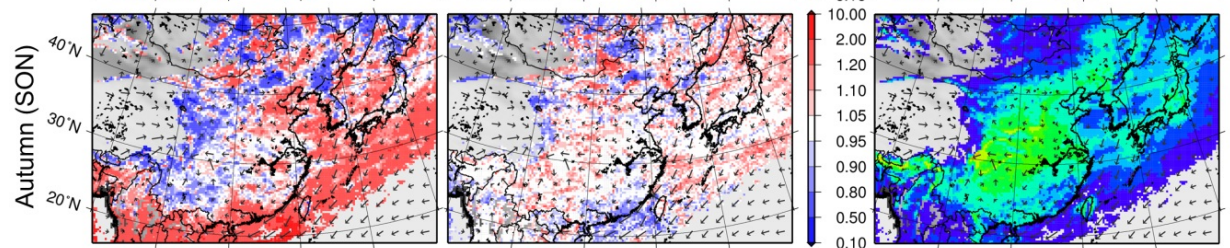

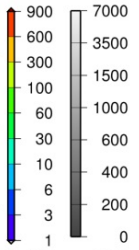
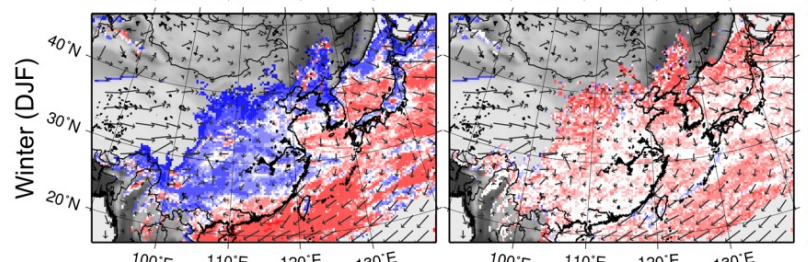

$\overrightarrow{10 \mathrm{~m} \mathrm{~s}^{-1}}$

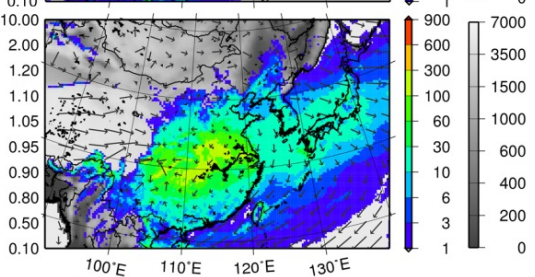

Figure 6: Same as Fig. 5 but for wet deposition.

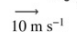


Geosci. Model Dev. Discuss., https://doi.org/10.5194/gmd-2018-128 Manuscript under review for journal Geosci. Model Dev.

Discussion started: 21 June 2018

(c) Author(s) 2018. CC BY 4.0 License.

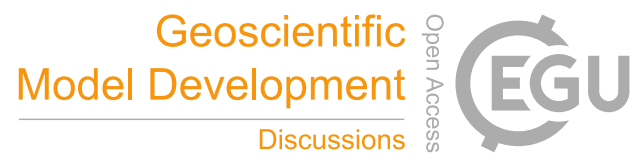

(c) $\underset{\mathrm{BY}}{\mathrm{B}}$
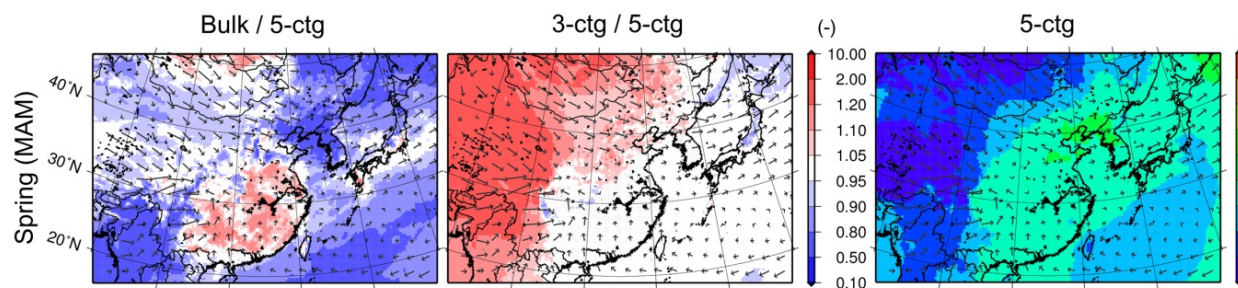

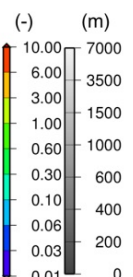
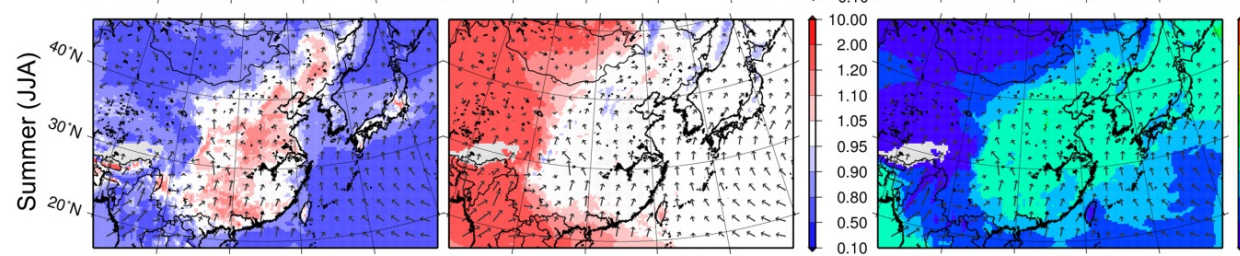

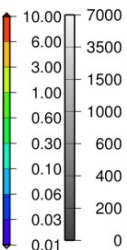
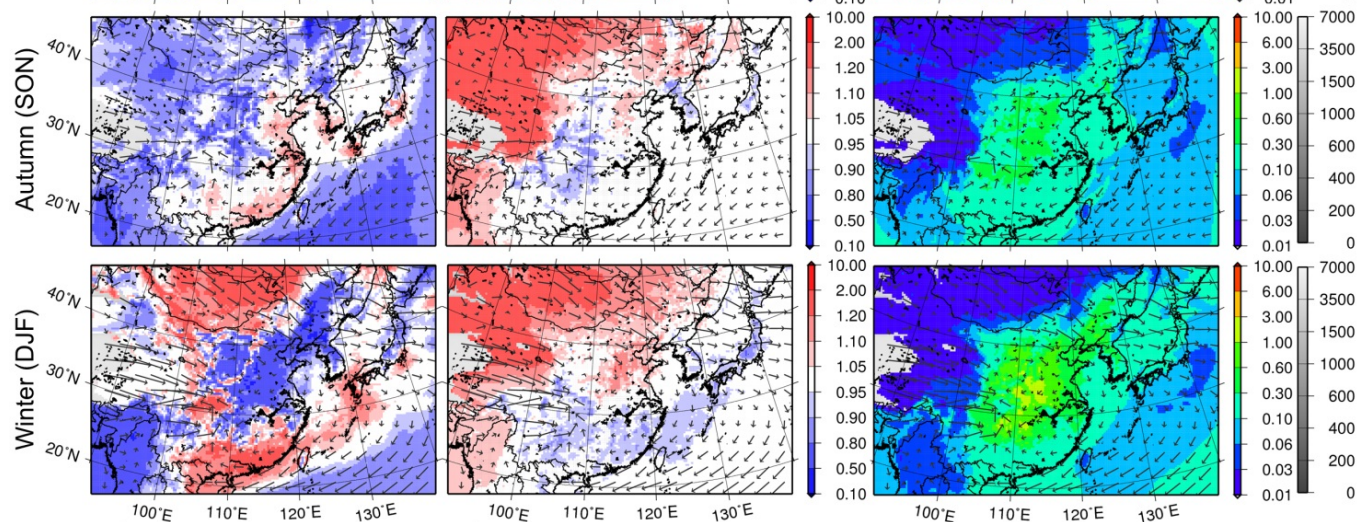

Figure 7: Same as Figs. 3-6 but for AOT (at $500 \mathrm{~nm}$ ) below approximately $1 \mathrm{~km}$ AGL. The wind vectors are also averaged within $1 \mathrm{~km}$ AGL. 
Geosci. Model Dev. Discuss., https://doi.org/10.5194/gmd-2018-128 Manuscript under review for journal Geosci. Model Dev.

Discussion started: 21 June 2018

(c) Author(s) 2018. CC BY 4.0 License.

(c) (1)
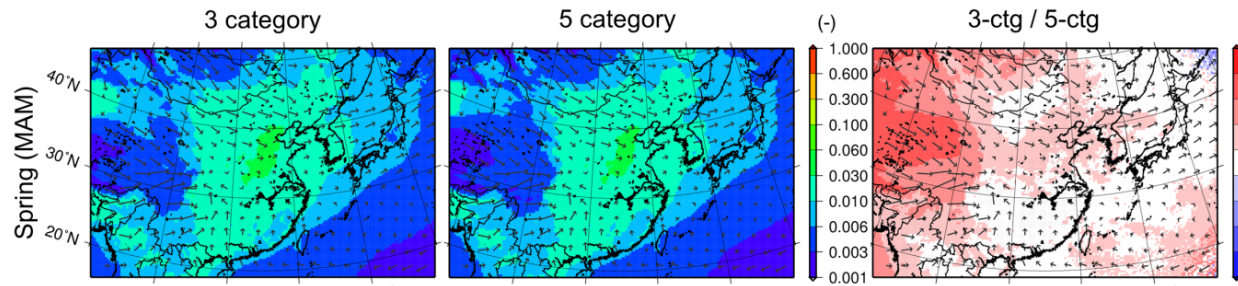

$(-) \quad(m)$
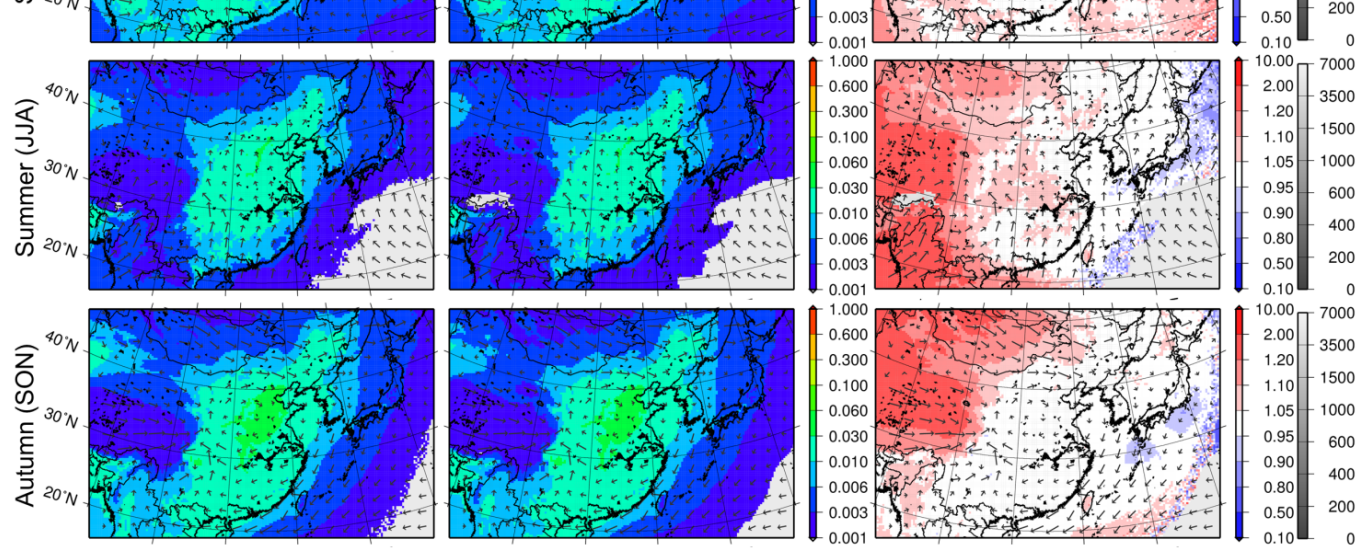

${ }^{10.00} \pi^{7000}$
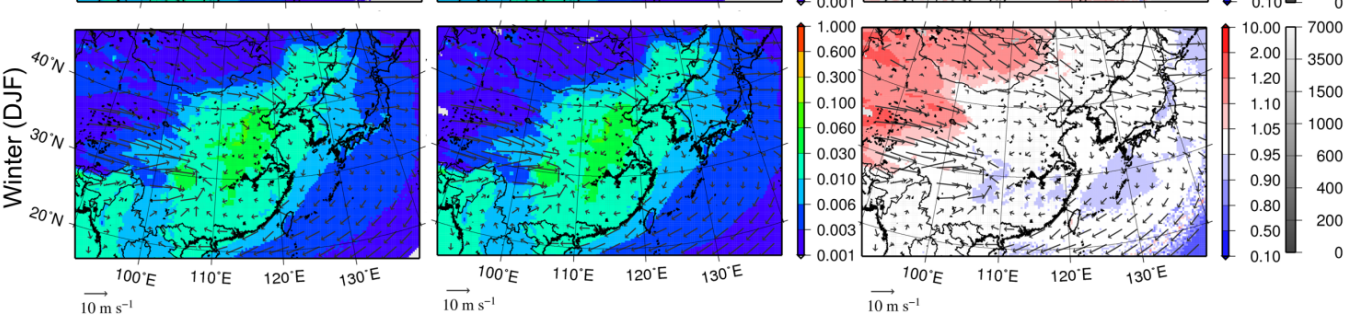

Figure 8: Same as Fig. 7 but for AAOT (at $500 \mathrm{~nm}$ ) for (left to right) the 3-category method, the 5-category method, and the ratios of the 3-category to 5-category methods. 
Geosci. Model Dev. Discuss., https://doi.org/10.5194/gmd-2018-128 Manuscript under review for journal Geosci. Model Dev.

Discussion started: 21 June 2018

(c) Author(s) 2018. CC BY 4.0 License.

(c) (1)
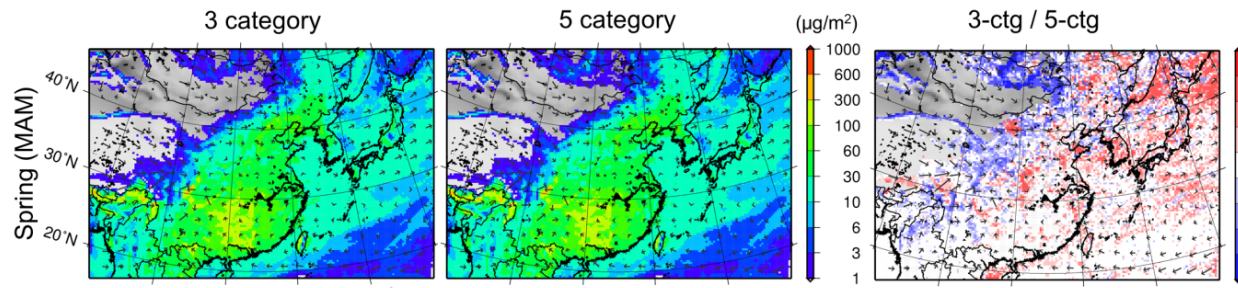

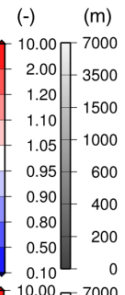
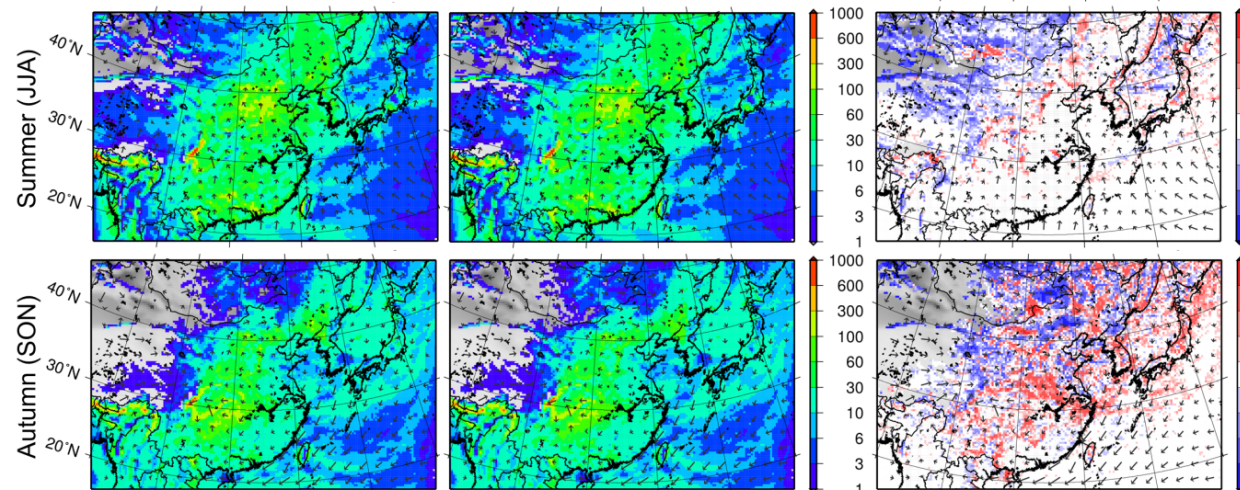

10.00
2.00 $\pi \begin{array}{r}7000 \\ 3500\end{array}$
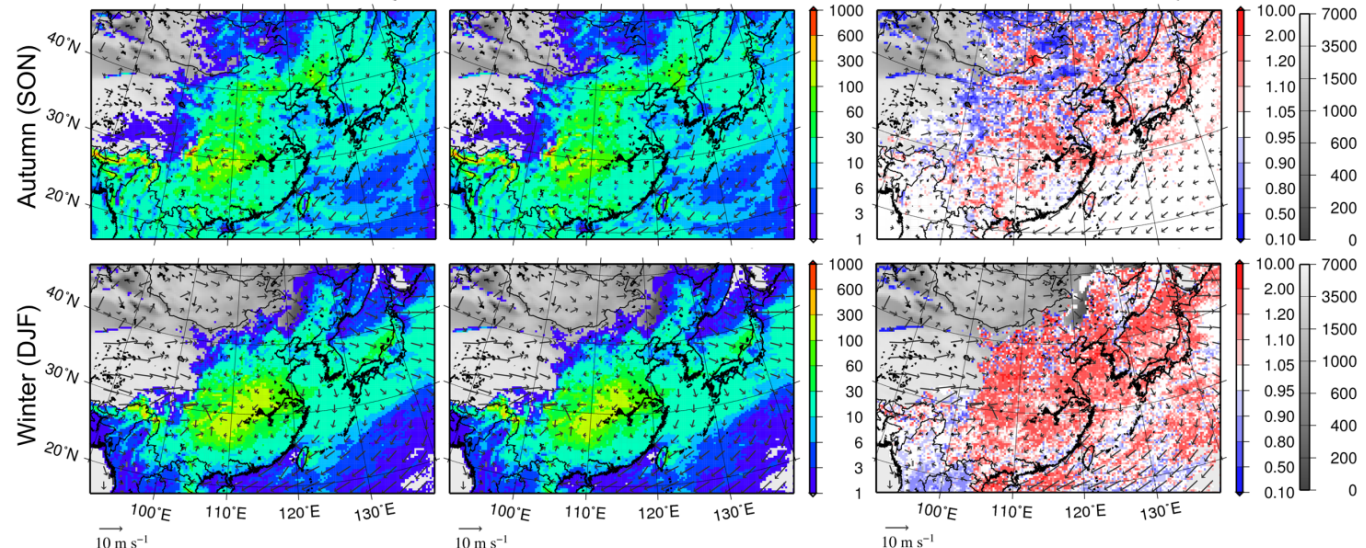

Figure 9: Same as Figs. 5 and 6 but for the total (dry + wet) deposition of BC for (left to right) the 3-category method, the 5-category method, and the ratios of the 3-category to 5-category methods. 
Geosci. Model Dev. Discuss., https://doi.org/10.5194/gmd-2018-128

Manuscript under review for journal Geosci. Model Dev.

Discussion started: 21 June 2018

(c) Author(s) 2018. CC BY 4.0 License.

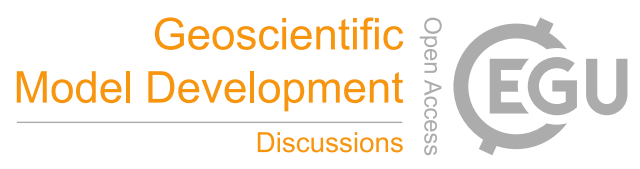

\section{(c) (i)}
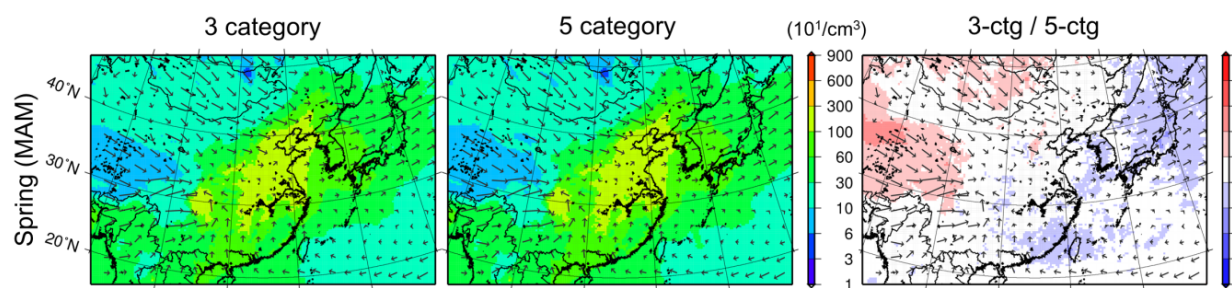

$\begin{array}{cc}(-) & (\mathrm{m}) \\ -10.00 \\ 2.00 \\ 1.20 \\ 1.10 \\ 1.05 \\ 0.95 \\ 0.90 \\ 0.80 \\ 0.800 \\ 0.50 \\ -3500 \\ -1500 \\ -1000 \\ 0.10 \\ 0\end{array}$
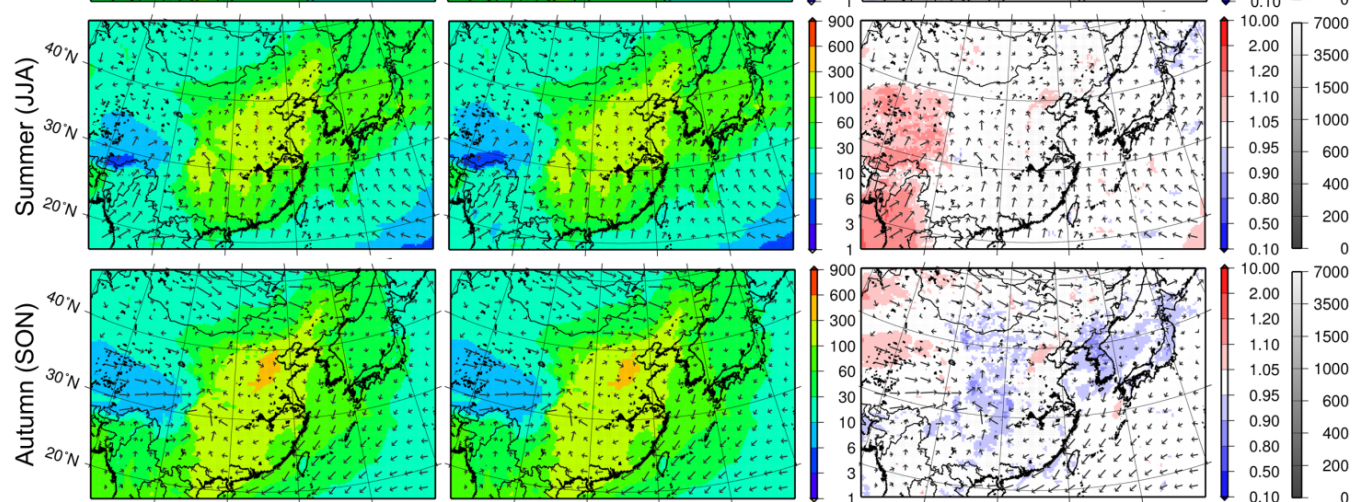

10.007000
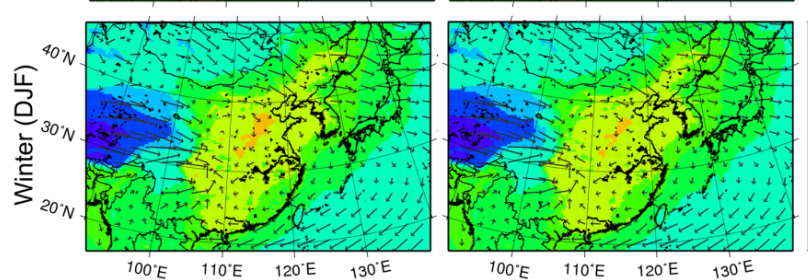

$\overrightarrow{10 \mathrm{~m} \mathrm{~s}^{-1}}$

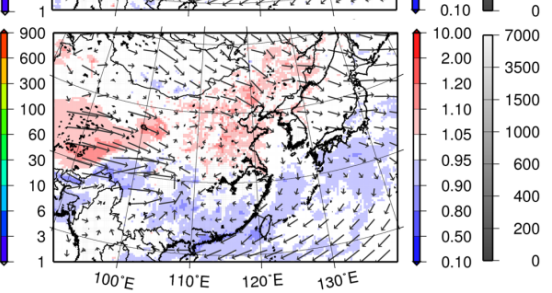

Figure 10: Same as Fig. 8 but for the averaged CCN number concentration below approximately $1 \mathrm{~km}$ AGL at a supersaturation of $0.1 \%$. 
Geosci. Model Dev. Discuss., https://doi.org/10.5194/gmd-2018-128

Manuscript under review for journal Geosci. Model Dev.

Discussion started: 21 June 2018

(c) Author(s) 2018. CC BY 4.0 License.
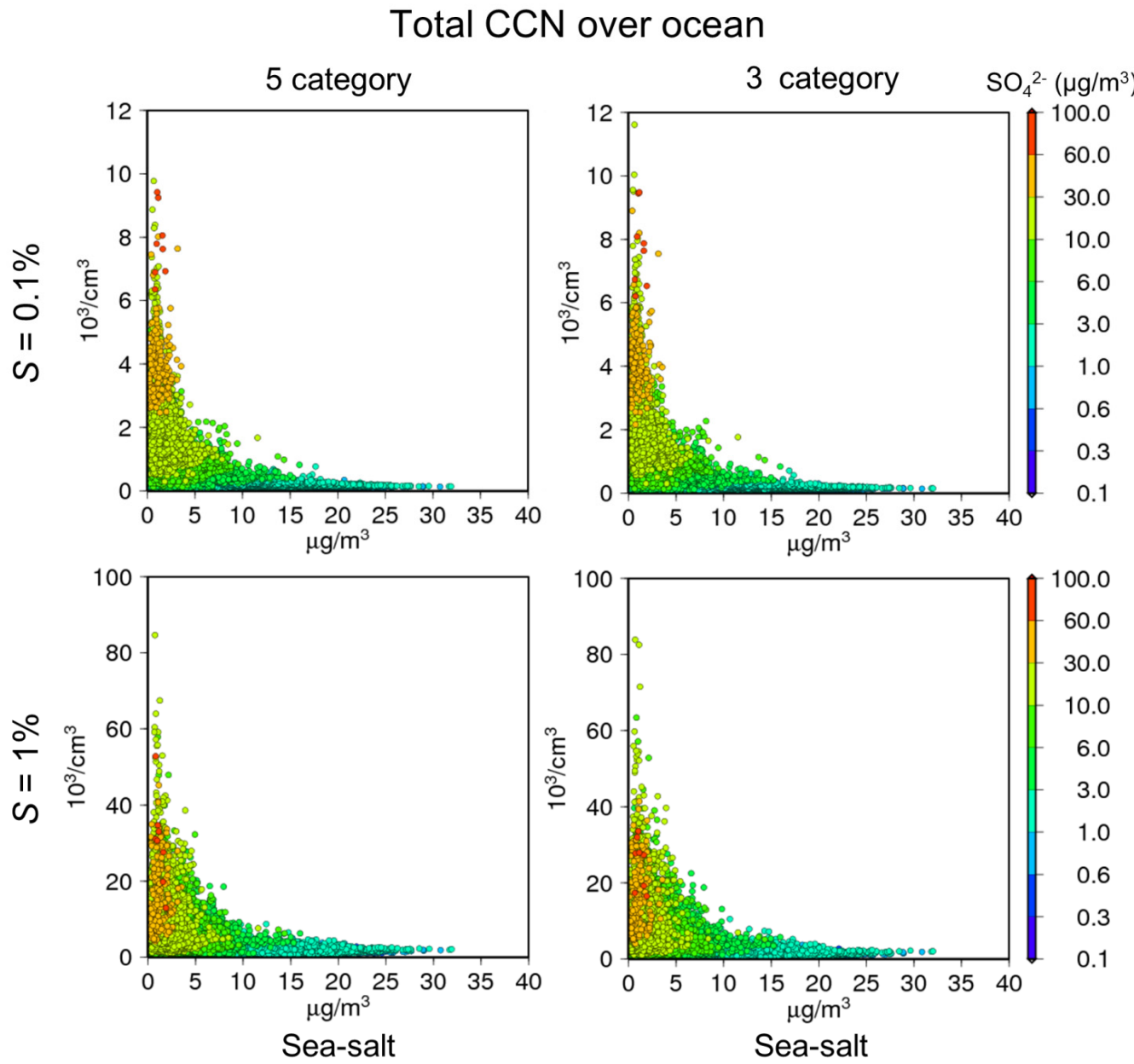

Figure 11: Scatter diagrams between the daily mean, averaged-below-1-km-AGL, total CCN number concentrations (y-axis) and dry mass concentrations of sea-salt (x-axis) together with $\mathrm{SO}_{4}{ }^{2-}$ concentrations (colors) over the ocean grids for the year 2006. The number of data points was randomly reduced to approximately one-twentieth in order to avoid too much overlapping of the points at supersaturation conditions of (top) $0.1 \%$ and (bottom) $1 \%$ for (left) the 5-category and (right) 3-category methods. 
Geosci. Model Dev. Discuss., https://doi.org/10.5194/gmd-2018-128

Manuscript under review for journal Geosci. Model Dev.

Discussion started: 21 June 2018

(c) Author(s) 2018. CC BY 4.0 License.
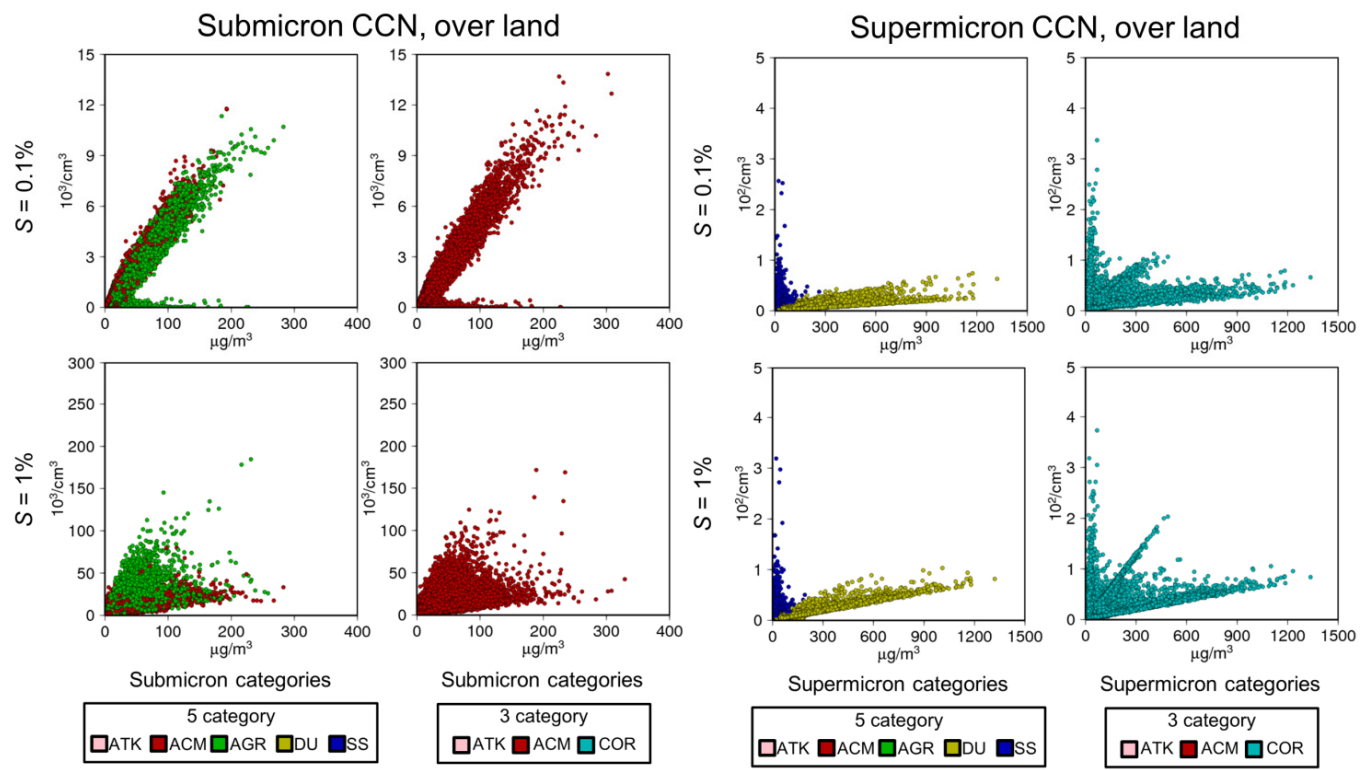

Figure 12: Same as Fig. 11 but for CCN over the land grids from (left four panels) submicron categories (i.e., ATK, ACM, and AGR for the 5-category method and ATK and ACM for the 3-category method), and (right four panels) supermicron categories (i.e., DU and SS for the 5-category method and COR for the 3-category method). X-axes are the total dry mass concentrations of submicron (left four panels) and supermicron (right four panels) categories. The colors of the dots correspond to those of the categories in the legends with the most dominant mass concentrations of the grids. 
Geosci. Model Dev. Discuss., https://doi.org/10.5194/gmd-2018-128

Manuscript under review for journal Geosci. Model Dev.

Discussion started: 21 June 2018

(c) Author(s) 2018. CC BY 4.0 License.
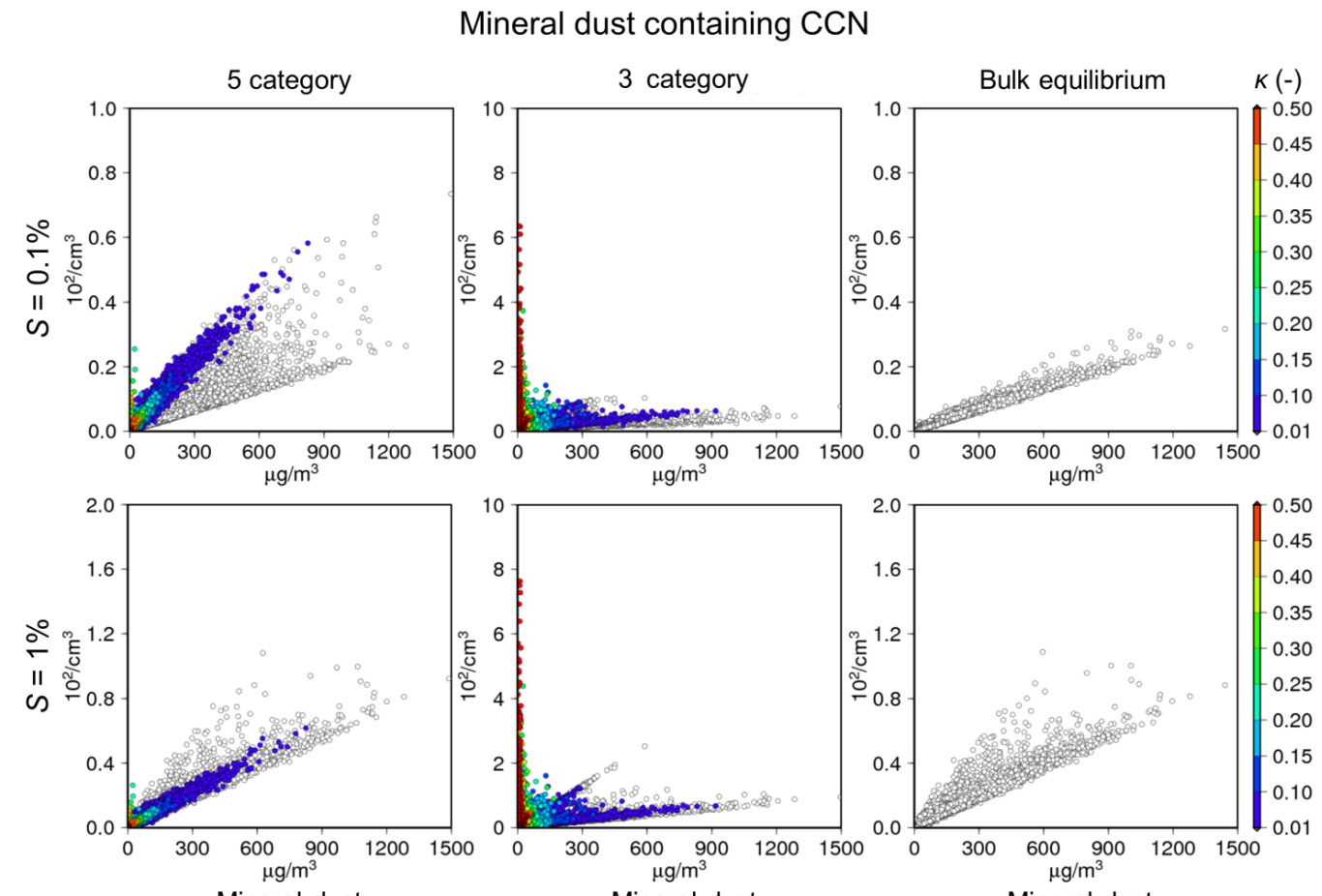

Figure 13: Same as Fig. 11 but for mineral dust containing CCN (y-axis) and mineral dust mass concentration (xaxis) together with hygroscopicity $\boldsymbol{\kappa}$ (colors) for (left to right) the 5-category, 3-category, and bulk methods. The color of the circles is white for $\boldsymbol{\kappa}$ smaller than 0.01 . 
Geosci. Model Dev. Discuss., https://doi.org/10.5194/gmd-2018-128 Manuscript under review for journal Geosci. Model Dev.

Discussion started: 21 June 2018

(c) Author(s) 2018. CC BY 4.0 License.

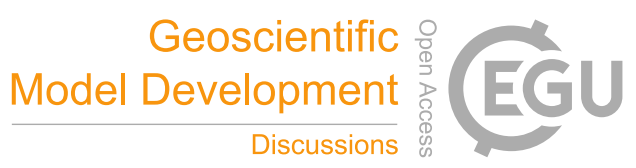

(c) (i)
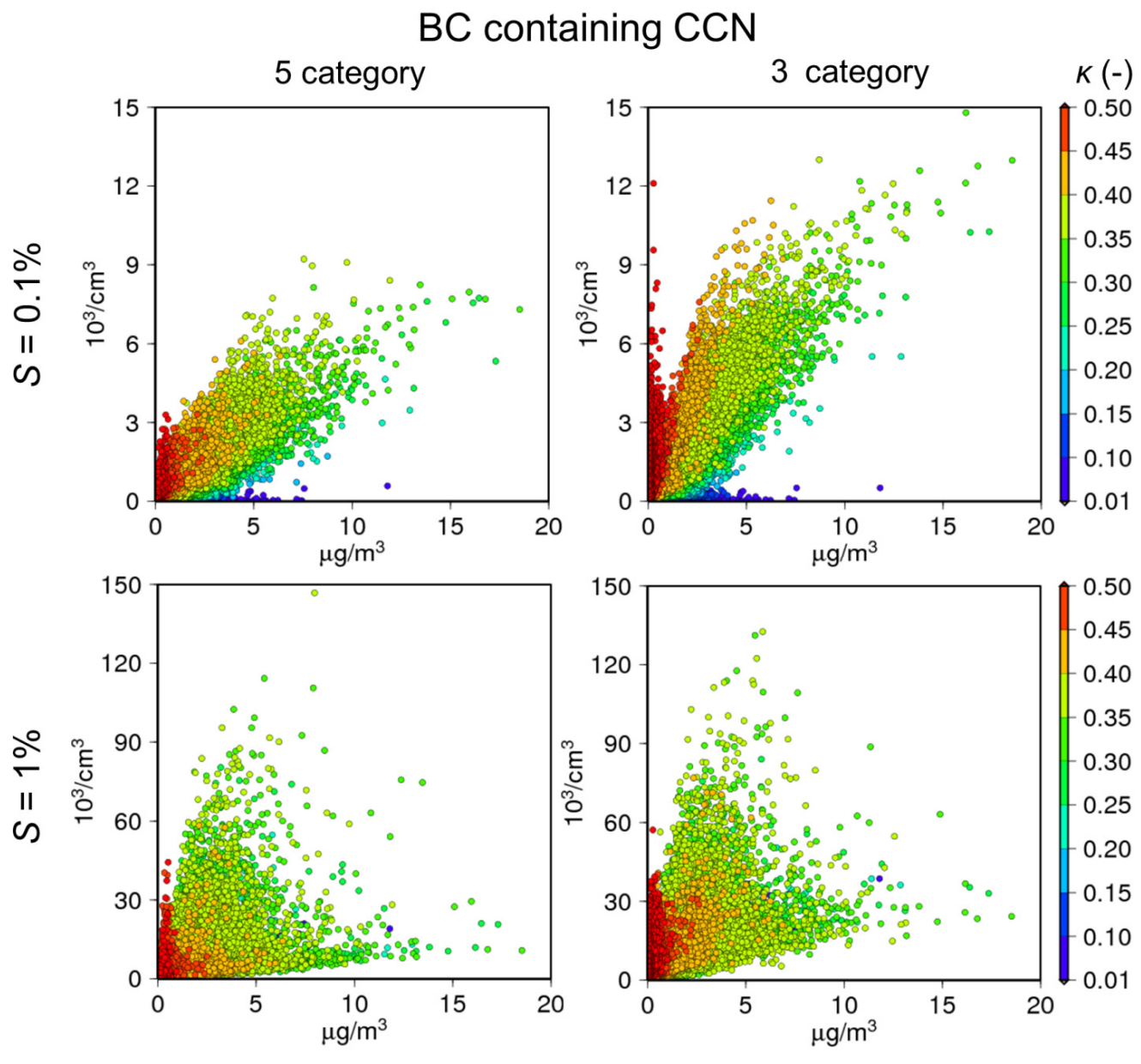

$\mathrm{BC}$

$\mathrm{BC}$

Figure 14: Same as Fig. 13 but for $\mathrm{BC}$-containing $\mathrm{CCN}$ (y-axis) and $\mathrm{BC}$ mass concentration (x-axis) together with hygroscopicity $\kappa$ (colors) for (left) the 5-category and (right) 3-category methods. 
Geosci. Model Dev. Discuss., https://doi.org/10.5194/gmd-2018-128

Manuscript under review for journal Geosci. Model Dev.

Discussion started: 21 June 2018

(c) Author(s) 2018. CC BY 4.0 License.

Table 1: List of models, schemes, and database available for NHM-Chem

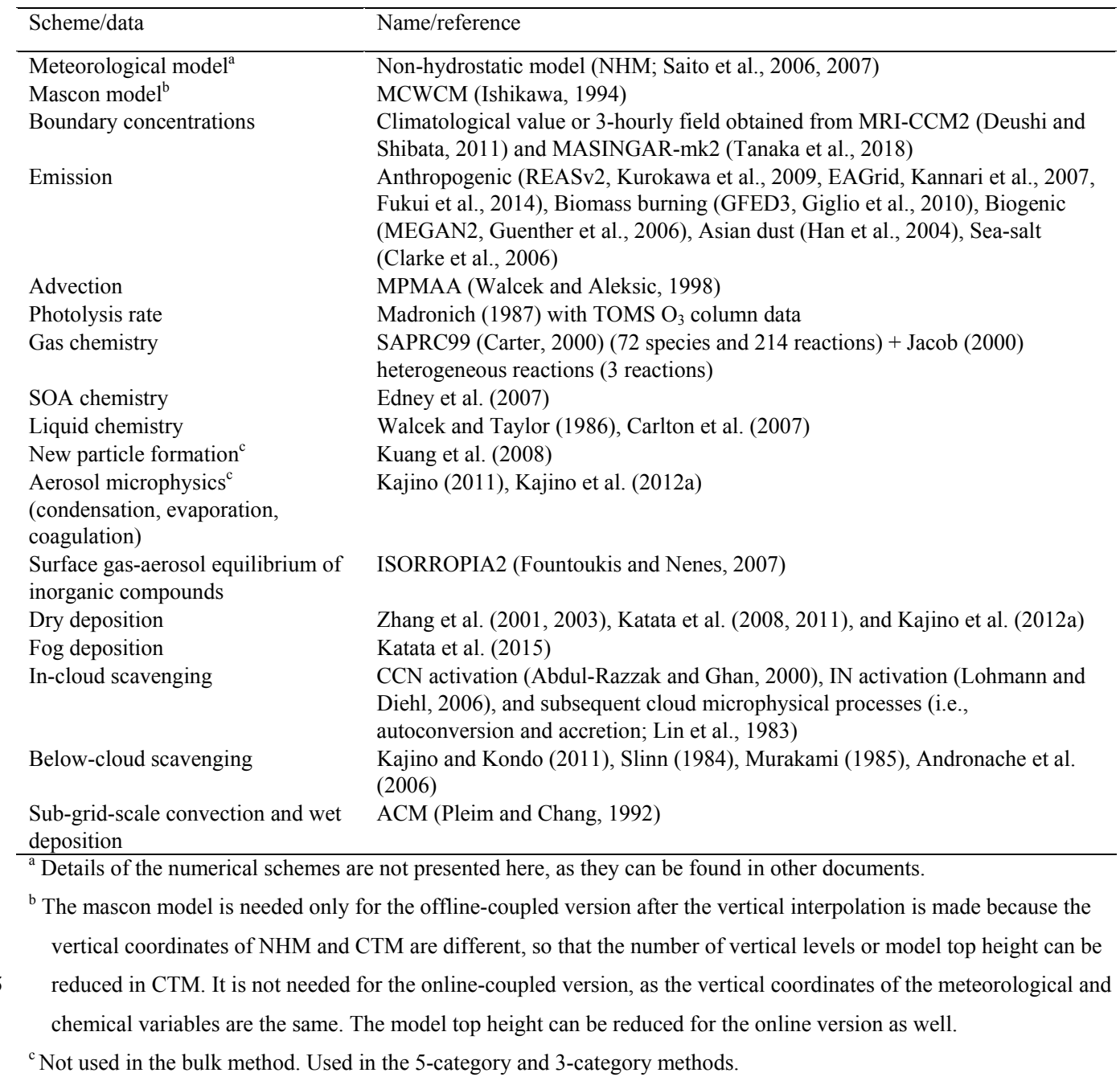


Geosci. Model Dev. Discuss., https://doi.org/10.5194/gmd-2018-128

Manuscript under review for journal Geosci. Model Dev.

Discussion started: 21 June 2018

(c) Author(s) 2018. CC BY 4.0 License.

Table 2: Prognostic variables of aerosol-related attributes

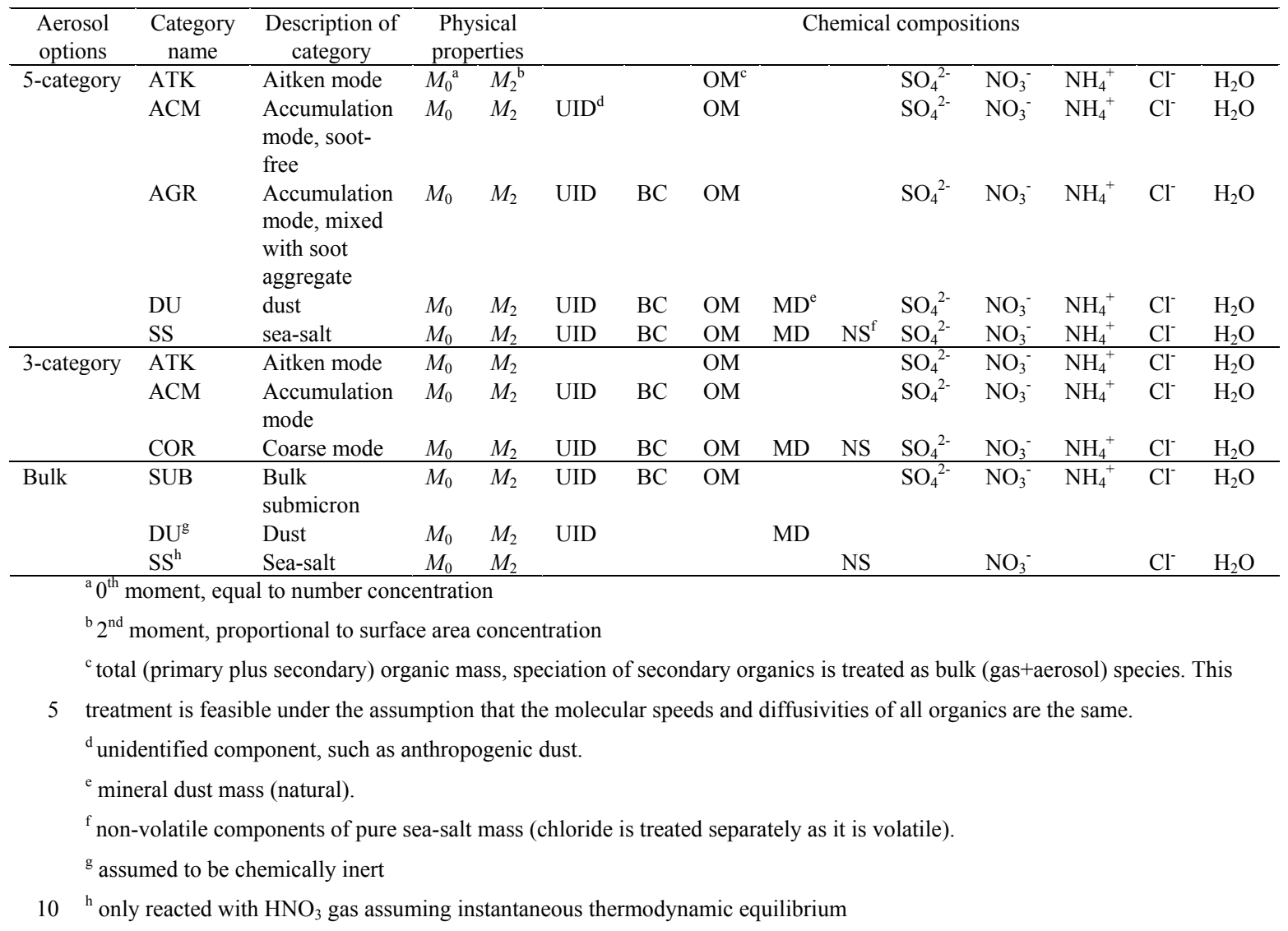


Geosci. Model Dev. Discuss., https://doi.org/10.5194/gmd-2018-128

Manuscript under review for journal Geosci. Model Dev.

Discussion started: 21 June 2018

(c) Author(s) 2018. CC BY 4.0 License.

Table 3: Rules for the transfer of moments and chemical mass concentrations from one category to another due to inter-category coagulation and mode merging

\begin{tabular}{|c|c|}
\hline $\begin{array}{c}\text { Aerosol } \\
\text { options }\end{array}$ & Rule \\
\hline 5-category & $\begin{array}{l}\text { Inter-category coagulation } \\
\mathrm{ATK}+\mathrm{ACM} \rightarrow \mathrm{ACM} \\
\mathrm{ATK}+\mathrm{AGR} \rightarrow \mathrm{AGR} \\
\mathrm{ATK}+\mathrm{DU} \rightarrow \mathrm{DU} \\
\mathrm{ATK}+\mathrm{SS} \rightarrow \mathrm{SS} \\
\mathrm{ACM}+\mathrm{AGR} \rightarrow \mathrm{AGR} \\
\mathrm{ACM}+\mathrm{DU} \rightarrow \mathrm{DU} \\
\mathrm{ACM}+\mathrm{SS} \rightarrow \mathrm{SS} \\
\mathrm{AGR}+\mathrm{DU} \rightarrow \mathrm{DU} \\
\mathrm{AGR}+\mathrm{SS} \rightarrow \mathrm{SS} \\
\mathrm{DU}+\mathrm{SS} \rightarrow \mathrm{SS} \\
\text { Mode merging } \\
\mathrm{ATK} \rightarrow \mathrm{ACM}\end{array}$ \\
\hline 3-category & $\begin{array}{l}\text { Inter-category coagulation } \\
\mathrm{ATK}+\mathrm{ACM} \rightarrow \mathrm{ACM} \\
\mathrm{ATK}+\mathrm{COR} \rightarrow \mathrm{COR} \\
\mathrm{ACM}+\mathrm{COR} \rightarrow \mathrm{COR} \\
\text { Mode merging } \\
\mathrm{ATK} \rightarrow \mathrm{ACM}\end{array}$ \\
\hline Bulk & n.a. \\
\hline
\end{tabular}

Table 4: Number of transport variables (gas plus aerosol attributes) $\left(N_{\text {trans }}\right)$ and ratios of the total CPU time to that of 5 the bulk-chemistry $\left(R_{\text {CPUtime }}\right)$, as well as ratios of CPU time of the aerosol process to that of the total processes ${ }^{1}\left(R_{\text {aero }}\right)$.

\begin{tabular}{llll}
\hline & $N_{\text {trans }}$ & $R_{\text {CPUtime }}$ & $R_{\text {aero }}(\%)$ \\
\hline Bulk equilibrium method & 78 & 1 & $15.0 \%$ \\
3-category non-equilibrium method & 96 & 1.44 & $46.0 \%$ \\
5-category non-equilibrium method & 108 & 1.91 & $54.9 \%$ \\
\hline
\end{tabular}

${ }^{\mathrm{T}}$ Excluding the I/O and MPI communications.

Table 5: Availability of volcanic emission data in Japan

\begin{tabular}{lllll}
\hline Volcano & $\begin{array}{l}\text { Longitude } \\
(\mathrm{E})\end{array}$ & $\begin{array}{l}\text { Latitude } \\
(\mathrm{N})\end{array}$ & $\begin{array}{l}\text { Height } \\
(\mathrm{m} \mathrm{MSL})\end{array}$ & Period \\
\hline Mt. Asama & $138^{\circ} 31^{\prime}$ & $36^{\circ} 24^{\prime}$ & 2,568 & July 4, 2002 - May 1, 2013 \\
Mt. Aso & $131^{\circ} 06^{\prime}$ & $32^{\circ} 53^{\prime}$ & 1,592 & March 22, 2007 - May 17, 2013 \\
Mt. Kirishima & $130^{\circ} 52^{\prime}$ & $31^{\circ} 56^{\prime}$ & 1,700 & January 27, 2011 - March 12, 2013 \\
Miyakejima (Mt. Oyama) & $139^{\circ} 31^{\prime}$ & $34^{\circ} 05^{\prime}$ & $775^{\mathrm{a}}$ & August 26, 2000 - May 17, 2013 \\
Mt. Sakurajima & $130^{\circ} 39^{\prime}$ & $31^{\circ} 35^{\prime}$ & 1,117 & May 23, 2007 - July 1, 2013 \\
\hline${ }^{a}$ ar & & &
\end{tabular}

${ }^{a}$ Previously $814 \mathrm{~m}$ before a huge eruption occurred in 2000

10 
Geosci. Model Dev. Discuss., https://doi.org/10.5194/gmd-2018-128

Manuscript under review for journal Geosci. Model Dev.

Discussion started: 21 June 2018

(c) Author(s) 2018. CC BY 4.0 License.

Table 6: Acronyms of aerosol size parameters and their relationships

\begin{tabular}{|c|c|c|}
\hline Acronym & Description & Relationship \\
\hline$\sigma_{\mathrm{g}}$ & Geometric standard deviation & \\
\hline$\rho_{\mathrm{p}, \mathrm{dry}}$ & Particle dry density $\left(\mathrm{g} / \mathrm{cm}^{3}\right)$ & \\
\hline$\rho_{\mathrm{p}}$ & Particle density $\left(\mathrm{g} / \mathrm{cm}^{3}\right)^{\mathrm{a}}$ & \\
\hline$D_{\mathrm{g}, \mathrm{n}, \mathrm{dry}}$ & Number-equivalent geometric mean dry diameter & \\
\hline$D_{\mathrm{g}, \mathrm{m}, \mathrm{dry}}$ & Mass-equivalent geometric mean dry diameter & $=D_{\mathrm{g}, \mathrm{n}, \mathrm{dry}} \times \exp \left(3 \times \ln \left(\sigma_{\mathrm{g}}\right)^{2}\right)$ \\
\hline$D_{\mathrm{g}, \mathrm{n}, \mathrm{aero}, \mathrm{dry}}$ & Aerodynamic $D_{\mathrm{g}, \mathrm{n}, \mathrm{dry}}$ & $=D_{\mathrm{g}, \mathrm{n}, \mathrm{dry}} \times \sqrt{ } \rho_{\mathrm{p}, \mathrm{dry}} \mathrm{b}$ \\
\hline$D_{\mathrm{g}, \mathrm{m}, \text { aero,dry }}$ & Aerodynamic $D_{\mathrm{g}, \mathrm{m}, \mathrm{dry}}$ & $=D_{\mathrm{g}, \mathrm{m}, \mathrm{dry}} \times \sqrt{ } \rho_{\mathrm{p}, \mathrm{dry}} \mathrm{b}$ \\
\hline$D_{\mathrm{g}, \mathrm{n}}$ & Number-equivalent geometric mean diameter ${ }^{a}$ & \\
\hline$D_{\mathrm{g}, \mathrm{m}}$ & Mass-equivalent geometric mean diameter ${ }^{a}$ & \\
\hline$D_{\mathrm{g}, \mathrm{n}, \text { aero }}$ & Aerodynamic $D_{\mathrm{g}, \mathrm{n}}$ & $=D_{\mathrm{g}, \mathrm{n}} \times \sqrt{\rho_{\mathrm{p}}}$ \\
\hline$D_{\mathrm{g}, \mathrm{m}, \text { aero }}$ & Aerodynamic $D_{\mathrm{g}, \mathrm{m}}$ & $=D_{\mathrm{g}, \mathrm{m}} \times \sqrt{\rho_{\mathrm{p}}} \mathrm{b}$ \\
\hline
\end{tabular}

${ }^{\mathrm{a}}$ When wet, or ambient

${ }^{a}$ For spheres 